\title{
The Eminence Of Risk-Free Rates In Portfolio Management: A South African Perspective
}

\author{
Chris van Heerden, North-West University, South Africa
}

\begin{abstract}
The traditional Capital Asset Pricing Model (CAPM) suggests that the minimum return required by an investor should be equal to the return of a risk-free asset (Reilly \& Brown, 2003), which should be stable (Reilly \& Brown, 2006), not influenced by external factors (Harrington, 1987), and certain (Bodie, Kane \& Marcus, 2010). Evidence, however, suggests that risk-free asset returns vary (Brunnermeier, 2008), and that "there is really no such thing as a truly riskless asset" (Brigham \& Ehrhardt, 2005:312). The pioneering studies of Mehra and Prescott (1985) and Weil (1989) only justified the size of the equity premium and risk-free rate puzzle but failed to provide a consensus on the specifications for the most ideal risk-free rate proxies. The results from this paper accentuated the problem of selecting a risk-free rate proxy, as all proxies under evaluation exhibited a level of risk and volatile returns. No regularities between the pre-, during and post-financial crisis regarding the choice of most ideal risk-free rate proxy were found. Overall findings suggested that the ideal proxies are the 3-month T-Bill rate and the 3-month NCD rate for the pre-, during and post-financial crisis periods, respectively.
\end{abstract}

Keywords: Omega Ratio; Risk Evaluation; Risk-Free Rate

\section{INTRODUCTION}

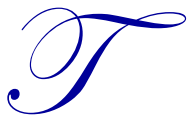

here is a general assumption that investors will require greater compensation (expected returns) from a riskier investment (Glosten, Jagannathan \& Runkle, 1993). The presence of business cycles (Harrison \& Zhang, 1999), financial crises (Ghysels, Plazzi \& Valkanov, 2013), tax laws and an evolving regulatory environment (Lo, 2004), and the changing risk appetite of investors (Misina, 2008), renders this risk-return relationship time-varying (Harrison \& Zhang, 1999). Under these ever-changing conditions investors must maintain an optimal group of assets that suits the preferred risk appetite, where Markowitz (1952) proposed a mean-variance approach to ensure optimal portfolio allocation. According to this approach, different assets are combined which minimise the variance for a given level of return. This implies that due to the linear relationship between the expected return and the risk (standard deviation) of a portfolio (Reilly \& Brown, 2003), investors will incessantly require a higher level of compensation (expected returns) as the level of market risk increases. To determine this level of expected returns relative to the market risk present, Sharpe (1964) and Lintner (1965) introduced the mean-variance Capital Asset Pricing Model (CAPM), which considers only the mean and variances of returns under the conditions of perfect market competition. Although, according to Black (1972), the greatest criticism of the mean-variance CAPM is the assumption of the presence of a 'riskless asset'. Brigham and Ehrhardt (2005:312) argue that "there is really no such thing as a truly riskless asset", which implies that the incorrect specification of a risk-free rate can lead to insufficient allocation of scarce resources (Bruner, Eades, Harris \& Higgins, 1998).

The implications of incorrectly specifying a risk-free rate also extends to the measuring of portfolio performance and to option pricing. Regarding the latter, the Black-Scholes model assumes that the risk-free rates are constant and known (Ray, 2012). This model is considered to be flawed as it assumes that risk-free rates exist, which is not the case in the real world (Ray, 2012). Also, there is evidence which suggest that risk-free rates are not constant, especially during times of uncertainty (Brunnermeier, 2008); it also contain information about future volatility (Glosten, Jagannathan \& Runkle, 1993); and are not always normally distributed (Van Heerden, 2015). The absence 
of normality influences the creditability of Markowitz's (1952) mean-variance approach, the mean-variance CAPM (Sharpe, 1964; Lintner, 1965) and risk-adjusted performance measures, as traditional risk measure, such as variance and the standard deviation, fail to capture higher moments (Amin \& Kat, 2003; Kat, 2003). This accentuates the probability of different performance rankings with the presence of non-normal risk-free returns (Van Heerden, 2015), and with no consensus in the specification of the most suited risk-free rate proxy as a performance benchmark/threshold will further hinder the credibility of performance measurement (see for example, De Wet, 2005; Botha, 2007; Samouilhan, 2007).

Overall, these findings pose significant problems for portfolio management in general, which prompted an inquiry to establish the best suited risk-free rate proxy during a pre-, during, and post-financial crisis period. The goal of this paper is thus to establish how risk-free are the risk-free rate proxies under evaluation over the three periods, and thus determine the ideal risk-free rate proxy to use from a South African perspective. This paper begins by evaluating the first prerequisite of a risk-free rate proxy, which states that it should exhibit a zero variation in returns over the investment horizon (Sharpe, 1964). This will be accomplished by evaluating the extent of volatility, which entails consulting an Exponential-Weighted Moving Average (EWMA) model (J.P. Morgan/Reuters, 1996), because the EWMA model has the ability to outperform multivariate Generalised AutoRegressive Conditional Heteroskedasticity (GARCH) models (Giamouridis \& Vrontos, 2007). The next step extends the evaluation of the risk present in the risk-free rate proxies, which consults the annualised covariance with the South African share market (Bodie, Kane \& Marcus, 2010), as a risk-free asset must not move in tandem with the market (Charteris \& Strydom, 2011). This is followed by consulting the most traditional risk measure, called the annualised standard deviation (derived from Sharpe, 1966).

However, as the standard deviation fails to incorporate the effects of higher moments (Van Heerden, 2015) and events such as downside surprises (Lamm, 2003), it thus provides a flawed perception of actual risk (Harlow, 1991). In order to address this, this paper will evaluate the descriptive statistics and level of normality of the risk-free rate proxies under evaluation in order to accentuate the importance to also consult several alternative risk measures. These risk measures will entail upside and downside risk (derived from Sortino \& Van der Meer, 1991; Keating \& Shadwick, 2002); maximum drawdown (derived from Young, 1991); deviation in the maximum drawdown (derived from Burke, 1994); and deviation in the maximum upturn, respectively. Downside and upside risk measure the uncertain possibility of losses and gains, respectively. Maximum drawdown and upturn, on the other hand, measure the maximum single peak-to-trough decline and maximum single trough-to-peak rise, respectively. In addition to these risk measures, it is also possible to evaluate the level of price risk of fixed coupon bonds. The price risk measure that will be consulted entails the bond price sensitivity if the yield-to-maturity would to change by 100 basis points. This estimation will be realised by examining both the approximate modified duration and convexity.

From the estimates provided by the risk measures mentioned above, this paper will also evaluate the creditability of previous studies which recommend the use of the already matured R157 bond as a risk-free rate proxy. Finally, to evaluate the reliability and stability of the different risk-free rate proxies under evaluation in terms of risk-adjusted performance, a static Omega ratio will be consulted. This is based on the notion that the returns of riskless assets must be stable over time compared to more risky assets (Reilly \& Brown, 2006). Though, to overcome the static perspective that is generated from the risk and performance measures in this paper, a 100-week rolling Omega ratio will be introduced. This paper illustrates the benefit of consulting a rolling Omega as a unique risk stability measure, as it provides a unique perspective of how risk evolved over time of a risk-free rate proxy.

In order to achieve these goals this paper commences by elaborating on the characteristics and specifications of a risk-free rate proxy (Section 2). Section 3 discusses the risk evaluation measures consulted in this paper (Section 3). This is followed by a discussion of the data in Section 4, where empirical results are reported in Section 5. Concluding remarks and recommendations are given in Section 6.

\section{THE CHARACTERISTICS AND SPECIFICATION OF A RISK-FREE RATE PROXY}

According to Sharpe (1964), the return on a risk-free asset must be equal to the pure interest rate, which implies that the real return must only depend on the time preference for generating wealth and the availability of investment opportunities. Also, the returns on a risk-free asset must not move in tandem with the market (Charteris \& Strydom, 
2011); should not be influenced by external factors, such as economic events and government policies (Harrington, 1987); and should be free from interest rate risk (which can be divided into price risk, reinvestment risk and refinancing risk), inflation risk, liquidity risk, currency risk, and default risk (Sharpe, 1964; Firer, 1993; Blake, 2000; Damodaran, 2001; Reilly \& Brown, 2006) thus, ensuring that the returns are stable over time compared to more risky assets (Reilly \& Brown, 2006). A portfolio with no market risk must, therefore, have an expected rate of return equal to the risk-free rate (Ray, 2012). This implies that the rate of return that can be earned on a risk-free asset must be certain (Bodie, Kane \& Marcus, 2010), where the return variance and the covariance with any risky asset must be zero (Sharpe, 1964).

However, as the theoretical requirements for and characteristics of a risk-free rate in portfolio management is abundantly clear, there is no consensus of which risk-free asset can be considered as the most appropriate proxy. There is a large divergence present in the literature, regarding the choice of both long-term and short-term risk-free rate proxies. For example, Copeland, Koller and Murrin (2000) and Samouilhan (2007) consider the 91-day Treasury Bill (T-Bill rate) rate as an appropriate proxy for evaluating portfolio performance. Bruner, Eades, Harris and Higgins (1998) also found that companies would usually choose between 3-month T-Bill rates or long-term Treasury bonds. Evidence of variation, co-movement (Carleton \& Lakonishok, 1985) and default risk (Nippani, Liu \& Schulman, 2001) have been found in both T-Bill rates and Treasury bonds, but studies by Moolman and Du Toit (2005) and De Wet (2005) consider the R157 bond yield and the R150 bond yield to be more applicable. Alternative studies also suggest the use of risk-free rates, such as the 10-year government bond yield (Copeland, Koller \& Murrin, 2000), 1-year T-Bill rate yields (De Villiers, Lowlings, Pettit \& Affleck-Graves, 1986), or the 12-month fixed deposit yield (Bradfield, Barr \& Affleck-Graves, 1988). Other studies such as Botha (2007) and Favre-Bulle and Pache (2003) recommended applying the 3-month JIBAR rate and the 3-month LIBOR rate, respectively. Firer, Ross, Westerfield and Jordan (2008), however, argue that Banker's Acceptances (BAs) have lower risk and higher liquidity, whereas Correia and Uliana (2004) and Viviers, Bosch, Smit and Buijs (2008) emphasised the use of Negotiable Certificates of Deposit (NCDs) as a risk-free rate proxy. Related studies, such as Oldham and Kroeger (2005) and Msweli-Mbanga and Mkhize (2007), also considered BA rates as a more appropriate risk-free rate proxy. On the other hand, a unique approach by Black (1972) suggested the use of the returns on a minimum-variance zerobeta portfolio as a suitable surrogate if a risk-free asset cannot be identified.

Nonetheless, the concept of a risk-free rate is only appropriate in a country which is free of default risk (Damodaran, 2001), and with evidence suggesting that the level of default risk increased during the 2007-2009 financial crisis (see for example, Allen, Hortaçsu \& Kastl, 2011), the specification of any risk-free rate proxy will be debateable. Though, Grandes, Peter and Pinaud (2003) confirmed that the estimated risk premium varied substantially even before the global financial crisis, which implies that default risk may have diluted the choice of a risk-free rate proxy indefinitely. Also, evidence of both currency and default risk premiums have been found in the yields of some longand short-term Treasury securities. Grandes and Pinaud (2004) and Hearn and Piesse (2009) further expressed concern regarding the high and variable risk premiums that are associated with some T-Bill rates. Another concern worth acknowledging is the problem of maturity mismatching, when considering an appropriate risk-free rate proxy, which can affect both bond valuations and the traditional CAPM model. The traditional CAPM evaluates an investment over a certain duration, which implies that when utilising a short-term risk-free rate proxy the necessity may present itself of rolling the risk-free investment over in order to comply with the longer duration of the project under evaluation. This implies that short-term risk-free rate proxies can introduce a certain level of reinvestment risk, as the risk-free asset no longer provides the insurance of a guaranteed return, which violates the condition of a zero variance. This is also true for the bond valuation model, which assumes that coupons earned can be reinvested at the same rate at which they are being earned (Blake, 2000). However, some evidence suggests that the returns on risk-free assets are unstable (Brunnermeier, 2008), which can generate a greater level of uncertainty, as unexpected fluctuations in long-term risk-free rates can lead to additional price and reinvestment risk. These arguments accentuate the importance of choosing the correct risk-free rate proxy to ensure more accurate portfolio allocation and more consistency in portfolio performance measurements.

\section{METHODOLOGY}

The first step of the empirical study is to evaluate the distribution characteristics of the different risk-free rate proxies under evaluation, as it constitutes one of the elementary building blocks that will ensure accurate financial 
analyses (Taylor, 1986). This evaluation entails examining the mean, kurtosis, skewness, and determining the level of normality present in the distribution series. The later will be determined by consulting several normality tests, based on the empirical distribution function (EDF), moments and correlation, respectively, to generate more conclusive results (Van Heerden \& Van Vuuren, 2015). The normality tests that are based on the EDF include the Kolmogorov-Smirnov (KS) tests (Kolmogorov, 1933; Smirnov, 1939) with the Lilliefors correction, the Cramér-von Misses' (CVM) test (Cramér, 1928; Von Mises, 1931) and the Anderson-Darling (AD) test (Anderson \& Darling, 1952). Normality tests that are based on moments and correlation will entail the Jarque-Bera (JB) test (Jarque \& Bera, 1987) and the Shapiro-Wilk (SW) test (Shapiro \& Wilk, 1965), respectively. This analysis was conducted with the EViews 7 program (QMS, 2009) and the IBM $^{\circledR}$ SPPS Statistics, version 22 program (IBM, 2013), respectively. However, Reschenhofer (2004) suggests that structural breaks can occur in higher moments, which can be misinterpreted as a deviation from normality.

Although, many of the models proposed to identify structural breaks are not always robust against heavy tails or require that the location of possible breaks are specified prior or do not allow for dependence in the data under investigation (Reschenhofer, 2004). Furthermore, alternative distributional stability models, such as Inoue's (2001) non-parametric test is unable to provide meaningful estimates of break locations in the presence of multiple breaks. From these findings it can be argued that it is difficult to detect multiple structural breaks accurately and to distinguish between structural breaks and other non-stationarity-like smooth transitions (see for example Reschenhofer, 1997). There is also no clear indication on how these structural breaks can be eliminated effectively, so this paper will not account for the possible presence of structural breaks in the higher moments.

The second step of empirical study will be to evaluate the level of risk exposure of several risk-free rate proxies over the pre-, during and post-financial crisis periods. This step will commence by establishing if the prerequisite of these risk-free assets, having a zero variation in the returns, is satisfied. This will be accomplished by consulting the Exponential-Weighted Moving Average (EWMA) model, which can be formulated as follows (J.P. Morgan/Reuters, 1996):

$$
\text { Level of volatility }(E W M A)=\sqrt{(1-\lambda) \sum_{t=1}^{\mathrm{T}} \lambda^{\mathrm{t}-1}\left(\mathrm{R}_{\mathrm{t}}-\overline{\mathrm{R}}\right)^{2}},
$$

where the EWMA model depends on the decay factor, $\lambda(0<\lambda<1)$, which determines the relative weights that must be applied to returns. In estimating the decay factor the following steps must be followed (J.P. Morgan/Reuters, 1996):

Firstly, $\Pi$ must be calculated. This can be achieved by taking the sum of all $\mathrm{N}$ minimal Root-Mean-Square-Errors (RMSE), $\tau \mathrm{s}:$

$$
\Pi=\sum_{\mathrm{i}=1}^{\mathrm{N}} \tau_{\mathrm{i}}
$$

where

$$
\operatorname{RMSE}_{v}=\frac{1}{\mathrm{~T}} \sum_{\mathrm{t}=1}^{\mathrm{T}}\left(\mathrm{R}_{\mathrm{t}+1}^{2}-\widehat{\sigma}_{(\mathrm{t}+1 \mid \mathrm{t})}^{2}\right)^{2}
$$

Then, the relative error measure is:

$$
\Theta_{i}=\frac{\tau_{i}}{\sum_{i=1}^{N} \Theta_{i}^{-1}} .
$$

Once the relative error measure is defined, the weight is:

$$
\phi_{\mathrm{i}}=\frac{\Theta_{\mathrm{i}}^{-1}}{\sum_{\mathrm{i}=1}^{\mathrm{N}} \Theta_{\mathrm{i}}^{-1}},
$$


where

$$
\sum_{\mathrm{i}=1}^{\mathrm{N}} \phi_{\mathrm{i}}=1
$$

Finally, the optimal decay factor $\tilde{\lambda}$ is (J.P. Morgan/Reuters, 1996):

$$
\tilde{\lambda}=\sum_{\mathrm{i}=1}^{\mathrm{N}} \phi_{\mathrm{i}} \tilde{\lambda}_{\mathrm{i}}
$$

where the final optimal decay factor applied is the weighted average of individual optimal decay factors. The third step of the empirical study extends the evaluation of risk present, which evaluates the annualised covariance with the share market (Bodie, Kane \& Marcus, 2010), as a risk-free asset must not move in tandem with the market (Charteris \& Strydom, 2011). This is followed by an array of several risk measures, which involves the annualised standard deviation (derived from Sharpe, 1966); the upside and downside risk (derived from Sortino \& Van der Meer, 1991; Keating \& Shadwick, 2002); the maximum drawdown (derived from Young, 1991); the deviation in the maximum drawdown (derived from Burke, 1994); and the deviation in the maximum upturn, which are, respectively:

$$
\begin{aligned}
& \text { Annualised covariance }=\frac{\sum\left(\mathrm{R}_{\mathrm{i}}-\overline{\mathrm{R}}_{\mathrm{i}}\right) \times\left(\mathrm{R}_{\mathrm{m}}-\overline{\mathrm{R}}_{\mathrm{m}}\right)}{\mathrm{n}}, \\
& \text { Annualised standard deviation }=\left(\sqrt{\frac{\sum\left(\mathrm{R}_{\mathrm{i}}-\overline{\mathrm{R}}_{\mathrm{i}}\right)^{2}}{\mathrm{n}}}\right) \times \sqrt{52}, \\
& \text { Upside risk }=\left(\sqrt{\frac{1}{\mathrm{n}} \sum_{\left(\mathrm{r}_{\mathrm{i}}-\mathrm{r}_{\mathrm{f}}\right)>0}^{\mathrm{N}} \mathrm{R}_{\mathrm{i}}^{2}}\right) \times \sqrt{52}, \\
& \text { Downside risk }=\left(\sqrt{\frac{1}{\mathrm{n}} \sum_{\left(\mathrm{r}_{\mathrm{i}}-\mathrm{r}_{\mathrm{f}}\right)<0}^{\mathrm{N}} \mathrm{R}_{\mathrm{i}}^{2}}\right) \times \sqrt{52}, \\
& \text { Maximum drawdown }(\mathrm{MD})=\max _{\mathrm{u}} \in[0, \mathrm{t}][\mathrm{P}(\mathrm{u})-\mathrm{T}(\mathrm{u})], \\
& \text { Deviation in maximum drawdown }=\sqrt{\sum_{\mathrm{k}=1}^{\mathrm{K}} \mathrm{MD}_{\mathrm{ik}}^{2}}, \\
& \text { Deviation in maximum upturn }=\sqrt{\sum_{\mathrm{l}=1}^{\mathrm{L}} \mathrm{MU}_{\mathrm{il}}^{2}},
\end{aligned}
$$

where $R_{i}$ is the weekly return observation of asset $i ; \bar{R}_{i}$ is the average of all the return observations of asset $i ; R_{m}$ is the weekly return observation of the market; $\bar{R}_{m}$ is the average of all the return observations of the market; $n$ is the number of observations under evaluation; and where $\mathrm{MU}$ is the maximum upturn, which can be formulated as follows:

$$
\text { Maximum upturn }(M U)=\max _{u \in[0, t]}[T(u)-P(u)],
$$

where $\mathrm{P}(\mathrm{u})$ is the return value at the peak over the interval of size $\mathrm{t}$; $\mathrm{T}(\mathrm{u})$ is the return value of the following trough over the interval of size $t ; \mathrm{K}$ is the number of drawdowns of asset $\mathrm{i}$; and $\mathrm{L}$ is the number of upturns of asset $\mathrm{i}$.

In additional to the above mentioned risk measures, this paper will also evaluate the price risk of the fixed coupon bonds under evaluation, which will be accomplished by means of consulting the bond price sensitivity if the yieldto-maturity would to change by 100 basis points. This estimation will be realised by examining both the approximate modified duration and convexity. The modified duration provides additional information regarding the 
extent to which the price of the bond will change (in percentage terms) for a given change in its yield-to-maturity (Koch \& Macdonald, 2003; Rose \& Hudgins, 2010). However, modified duration can only be obtained if the Macaulay duration for the period under evaluation is already known. An alternative to this approach, and which this paper applies, is to approximate modified duration directly by estimating Equation 14. The objective of this approximation is to estimate the slope of the price-yield curve. To estimate the slope the yield-to-maturity is changed up and down by the same amount ( $\Delta$ yield), which enables the estimation of the bond prices at each new yield-to-maturity (Adams \& Smith, 2015). Although, like modified duration, the approximate modified duration still assumes that there is a linear relationship between the price and yield of the bond. This can be remedied by adjusting the approximate modified duration with an approximate convexity (Equation 15) estimate (Adams \& Smith, 2015). Convexity is viewed as an important risk-management tool when considering the measurement of price risk, as it provides additional insight as to how investors will experience losses from fluctuations in the bond prices that are caused by non-parallel yield curve shifts (Koch \& Macdonald, 2003; Rose \& Hudgins, 2010). This will, enable a more true estimation of the price value of a basis point (Adams \& Smith, 2015). The estimation of bond price sensitivity with the change of 100 basis points $(\% \Delta \mathrm{PV})$ will serve as the price risk measure in this paper (Equation 16).

$$
\begin{aligned}
& \text { Approximate Modified Duration }(\mathrm{AMD})=\frac{\left(\mathrm{PV}_{-}\right)-\left(\mathrm{PV}_{+}\right)}{2 \times(\Delta \text { yield }) \times\left(\mathrm{PV}_{0}\right)}, \\
& \text { Approximate Convexity }(\mathrm{AC})=\frac{\left(\mathrm{PV}_{-}\right)+\left(\mathrm{PV}_{+}\right)-\left[2 \times\left(\mathrm{PV}_{0}\right)\right]}{(\Delta \text { yield })^{2} \times\left(\mathrm{PV}_{0}\right)} \\
& \% \Delta \mathrm{PV} \approx(-\mathrm{AMD} \times \Delta \text { yield })+\left[\frac{1}{2} \times \mathrm{AC} \times(\Delta \text { yield })^{2}\right]
\end{aligned}
$$

where $\mathrm{PV}_{-}$denotes the bond price when the yield is decreased; $\mathrm{PV}_{+}$denotes the bond price when the yield is increased; and $\mathrm{PV}_{0}$ denotes the original bond price (Adams \& Smith, 2015).

Finally, to evaluate the reliability and stability of the different risk-free rate proxies under evaluation in terms of risk-adjusted performance, a static Omega ratio will be consulted. This is based on the notion that the returns of riskless assets must be stable over time compared to more risky assets (Reilly \& Brown, 2006). Though, to overcome the static perspective that is generated from the risk and performance measures in this paper, a 100-week rolling Omega ratio is introduced as a unique risk stability measure. This rolling Omega provides a unique perspective of how risk evolved over time of a risk-free rate proxy. The Omega ratio, originally introduced by Keating and Shadwick (2002), includes all the information that is encoded in all the moments (variance, mean, skewness, and kurtosis) without any prior assumptions (De Wet, Krige \& Smit, 2008). It considers both the upside potential (higher partial moments) and downside potential (lower partial moments) of an investment over the entire distribution, which implies that it has the ability to treat upside and downside risk differently (Gilli, Schumann, Di Tollo \& Cabej, 2011:95). The Omega ratio is (Eling \& Schuhmacher, 2007):

$$
\Omega(r)=\frac{\int_{r}^{b}(1-F(x)) d x}{\int_{a}^{r} F(x) d x}
$$

where $\mathrm{r}$ denotes the selected threshold; $\mathrm{x}$ denotes the random one-period return of an investment; $\mathrm{a}$ and $\mathrm{b}$ denote the upper and lower bounds of the return distribution, respectively; $\int_{\mathrm{r}}^{\mathrm{b}}(1-\mathrm{F}(\mathrm{x})) \mathrm{dx}$ denotes the upside potential; and $\int_{\mathrm{a}}^{\mathrm{r}} \mathrm{F}(\mathrm{x}) \mathrm{dx}$ denotes the downside potential.

\section{DATA}

The time horizon under evaluation is divided into a pre-, during, and post-financial crisis period. The pre-financial crisis period spans January 2005 to December 2006, whereas the crisis period spans January 2007 to December 2009 and the post-financial crisis period January 2010 to August 2014. The starting point of the pre-financial crisis period was determined by the availability of the R186 bond rate and the different bond indices under evaluation, whereas the time span of the post-financial crisis period was determined by the availability of the R157 bond rate, as it 
matured on 15 September 2014. The reason for including the R157 bond rate was to evaluate the creditability of previous studies which recommended this bond as a suitable risk-free rate proxy.

Isolating all the effects of the financial crisis was difficult, so the crisis period was carefully determined in order to incorporate key events. This period starts at the date when the Federal Home Loan Mortgage Corporation (Freddie Mac) announced that no more risky subprime mortgages and mortgage-related securities would be purchased (27 February 2007). It continues by incorporating the event when Northern Rock was taken into state ownership by the Treasury of the United Kingdom (17 February 2008), and the announcements of Lehman Brothers Holdings Incorporated filing for bankruptcy on 15 September 2008. Lastly, it continues until after the announcement of the American Recovery and Reinvestment Act of 2009, which included a variety of tax cuts and spending measures that were intended to promote economic recovery in the United States (US).

Weekly risk-free rates (5-day averages) of several money market and capital market risk-free rate proxies were evaluated, as reported by Table 1. The extent of the proxies included in this paper was based on the historical findings and suggestions as already reported in Section 2. The South African 3-month Treasury Bill, the Negotiable Certificates of Deposits (NCDs) rates, the Benchmark Overnight Rate on Deposits rate (SABOR) and the overnight FX rate were obtained from the South African Reserve Bank's website (SARB, 2015), whereas the rest of the riskfree rate proxies were obtained from the INET BFA (2015) database. Note that the following risk-free rate proxies were excluded from this paper: the 12-month fixed deposit yield was excluded, as only yearly data were available; the 3-month Banker's Acceptances (BA) discount rate was excluded, as the data are only available until February 2014; the R153 bond rate was excluded, as it was only available until August 2009; and the R208 bond rate was excluded, as it was only available from November 2006. Finally, the JSE All Share index (J203) was utilised as the equity market proxy to estimate the level of covariance between the market index and the risk-free rate proxies under evaluation. The weekly J203 index values were obtained from the INET BFA (2015) database.

Table 1. The 21 risk-free rate proxies under evaluation

\begin{tabular}{l|l}
\hline \multicolumn{1}{c}{ Money market proxies } & \multicolumn{1}{c}{ Capital market proxies } \\
\hline 3-month Treasury Bill discount rate & R157 bond rate \\
\hline 3-month JIBAR yield & R186 bond rate \\
\hline 6-month JIBAR yield & R203 bond rate \\
\hline 12-month JIBAR yield & R204 bond rate \\
\hline Benchmark Overnight Rate on Deposits rate (SABOR) & 1-to-3-year bond index \\
\hline Rand Overnight Deposit rate & 3-to-7-year bond index \\
\hline 3-month Negotiable Certificates of Deposits (NCDs) rate & 7-to-12-year bond index \\
\hline 6-month Negotiable Certificates of Deposits (NCDs) rate & Over 12-year bond index \\
\hline 12-month Negotiable Certificates of Deposits (NCDs) rate & \\
\hline Overnight FX rate & \\
\hline 3-month Call Deposit index & \\
\hline 6-month Call Deposit index & \\
\hline 12-month Call Deposit index & \\
\hline $\begin{array}{l}\text { Source: Compiled by author. } \\
\text { Note: The overnight FX rate refers to the 1-day rate on Rand funding in the foreign exchange swap market. The annual yields were also } \\
\text { converted to weekly yields, respectively. This ensures that all the data under investigation are in the same format. }\end{array}$ \\
\hline
\end{tabular}

\section{RESULTS}

The empirical analyses commenced by evaluating the descriptive statistics of the risk-free rate proxies under evaluation, in order to accentuate the importance of consulting alternative risk measure rather than only relying on the standard deviation, which fails to provide a true reflection of actual risk (Harlow, 1991; Van Heerden, 2015). From the results reported by Table 2 and $\mathrm{A}$ in the Appendix it is evident that on average all the risk-free rate proxies under evaluation can be considered to be leptokurtic (peaked) for all three time periods. However, averages can be misleading, as all of the government bonds (R157, R186, R203, R204), the 12-month JIBAR and 12-month NCD rates were exceptions during the pre-financial crisis period, which exhibited platykurtic (flat) characteristics. This observation changed dramatically during the financial crisis period, when evaluating these proxies individually, where more than half of the risk-free rate proxies (13 of the 21) exhibited platykurtic (flat) characteristics. 
Nevertheless, this observation changed again during the post-financial crisis, where all except the R157, R186, R203, R204 and the 12-month JIBAR rate exhibited leptokurtic (peaked) characteristics (see Table A1 \& A2 in the Appendix).

Table 2. Summary of descriptive statistics

\begin{tabular}{l|c|c|c}
\hline \multicolumn{1}{c|}{ Averages } & Pre-financial crisis period & During financial crisis period & Post-financial crisis period \\
\hline Mean & $0.11 \%$ & $0.13 \%$ & $0.09 \%$ \\
\hline Max. & $0.84 \%$ & $1.19 \%$ & $0.46 \%$ \\
\hline Min. & $-0.32 \%$ & $-0.74 \%$ & $-0.36 \%$ \\
\hline Skew. & 1.02 & -0.01 & 0.35 \\
\hline Kurt. & 14.38 & 5.67 & 3.99 \\
\hline
\end{tabular}

Source: Compiled by author.

Note: Max. denotes maximum; Min. denotes minimum; Skew. denotes skewness; and Kurt. denotes kurtosis;

Note: Complete results are reported by Table A1 \& A2 in the Appendix.

Table 2 also reports that on overage the risk-free rate proxies under evaluation exhibited a positive skewness during the pre- and post-financial crisis periods, but a negative skewness during the financial crisis period. This same trend is also evident when evaluating the proxies individually, as reported by Table A1 \& A2 in the Appendix. Only the 12-month Call deposit index, R157, R203, and the R204 exhibited a negative skewness, whereas the rest of the proxies under evaluation exhibited a positive skewnss. This number escalated to 12 proxies during the financial crisis period, which exhibited a negative skewness and remained at a higher level (7 of 21) over the post-financial crisis period, compared to the pre-financial crisis period. Overall, these findings imply that financial analysts should still be cautious when consulting traditional risk-adjusted performance measures, as the presence of higher moments can corrode the accuracy of traditional performance measures.

To accentuate the effect of the higher moments five different normality tests were consulted to obtain more convincing results, which entail the Kolmogorov-Smirnov (KS) tests with the Lilliefors correction, the Cramér-von Misses' (CVM) test, the Anderson-Darling (AD) test, the Jarque-Bera (JB) test, and the Shapiro-Wilk (SW). From the results reported by Table 3 and $\mathrm{A}$ in the Appendix it is evident that the presence of non-normal returns is substantial over the three time periods under evaluation. During the pre-financial crisis period the 3-to-7-year bond index, 7-to-12-year bond index, over 12-year bond index, R203 and the R204 were the only exceptions which exhibited normal distributed returns. However, the during and post-financial crisis periods unveiled more compelling results, where all the risk-free rate proxies under evaluation exhibited non-normal return distributions. From these results the conclusion can be made that traditional risk measures, such as the standard deviation, will fail to provide a true reflection of actual risk, which is why the standard deviation results from Table B to D in the Appendix will not be discussed and will be excluded from the remaining empirical analysis. 
Table 3. Summary of normality tests

\begin{tabular}{|c|c|c|c|}
\hline & Pre-financial crisis period & During financial crisis period & Post-financial crisis period \\
\hline 1-to-3-year bond index & No & No & No \\
\hline 3-to-7-year bond index & Yes & No & No \\
\hline 7-to-12-year bond index & Yes & No & No \\
\hline Over-12-year bond index & Yes & No & No \\
\hline 3-month Call deposit index & No & No & No \\
\hline 6-month Call deposit index & No & No & No \\
\hline 12-month Call deposit index & No & No & No \\
\hline Overnight FX rate & No & No & No \\
\hline R 157 & No & No & No \\
\hline R 186 & No & No & No \\
\hline R 203 & Yes & No & No \\
\hline R 204 & Yes & No & No \\
\hline Rand overnight deposit rate & No & No & No \\
\hline 3-month JIBAR yield & No & No & No \\
\hline 6-month JIBAR yield & No & No & No \\
\hline 12-month JIBAR yield & No & No & No \\
\hline 3-month NCD rate & No & No & No \\
\hline 6-month NCD rate & No & No & No \\
\hline 12-month NCD rate & No & No & No \\
\hline 3-month T-Bill rate & No & No & No \\
\hline SABOR rate & No & No & No \\
\hline
\end{tabular}

The next step of the empirical analysis was to evaluate the level of volatility, risk and the risk-adjusted performance of each risk-free rate proxy under evaluation. This step is based on the prerequisites that risk-free assets should have no variation in their returns (Sharpe, 1964), should not move in tandem with the market (Charteris \& Strydom, 2011), their returns must be completely free of any type of risk, and their returns must be stable over time compared to more risky assets (Reilly \& Brown, 2006). This was accomplished by firstly evaluating the reliability and stability (variation) of the returns of the risk-free rate proxies under evaluation by means of a static Omega ratio. The Omega ratio was ideal for this paper as it incorporates all the higher moments and does not make any assumptions of normality. The Omega estimate for each risk-free rate proxy was estimated by assigning equal weights to both the upside and downside potential (see Equation 17). From the results reported by Table 4 it is evident that there were no regularities (stability) between the three time periods under evaluation when determining the most ideal risk-free rate proxy, which were also emphasised by the geometric returns reported by Table B to D. From these results it can already be argued that there was some level of variation and instability in the returns of the risk-free rate proxies under evaluation. Table 4 also shows that, based only on the static Omega estimates, the 3-month Call deposit index could have been considered as the most ideal risk-free rate proxy over the pre-financial crisis, which is also the only money market proxy under the top five rankings. However, this perspective changed for the during and postfinancial crisis periods, where the capital market proxies (bond indices) attained the top four rankings, with the 3-to7-year bond index and the 7-to-12-year bond index ranking first in the during and post-financial crisis periods, respectively. The money market proxies performed poorly in these periods, where the best money market proxies, entailing the overnight FX rate and the 3-month Call deposit index, ranked fifth in the during and post-financial crisis periods, respectively (see Table 4). It is also interesting to note that it was in some instances difficult to distinguish between the extremely small upside potential estimates of the proxies ranking from fifth place and lower, making it impossible to establish the least ideal risk-free rate proxies with the use of a static Omega ratio (see Table 4). 
Table 4. Summary of static Omega rankings

\begin{tabular}{|c|c|c|c|c|c|}
\hline \multicolumn{2}{|c|}{ PRE-FINANCIAL CRISIS PERIOD } & \multicolumn{2}{|c|}{$\begin{array}{l}\text { DURING FINANCIAL } \\
\text { CRISIS PERIOD }\end{array}$} & \multicolumn{2}{|c|}{$\begin{array}{l}\text { POST-FINANCIAL } \\
\text { CRISIS PERIOD }\end{array}$} \\
\hline Name & Ranking & Name & Ranking & Name & Ranking \\
\hline 3-month Call deposit index & 1 & 3-to-7-year bond index & 1 & 7-to12-year bond index & 1 \\
\hline 6-month Call deposit index & 2 & 1-to-3 year bond index & 2 & 3-to-7-year bond index & 2 \\
\hline 12-month Call deposit index & 3 & 7-to12-year bond index & 3 & Over-12-year bond index & 3 \\
\hline 7-to12-year bond index & 4 & Over-12-year bond index & 3 & 1-to-3 year bond index & 4 \\
\hline Over-12-year bond index & 4 & Overnight FX rate & 4 & 3-month Call deposit index & 5 \\
\hline 1-to-3 year bond index & 5 & 12-month Call deposit index & 5 & 6-month Call deposit index & 5 \\
\hline 3-to-7-year bond index & 6 & 12-month NCD rate & 6 & 12-month Call deposit index & 5 \\
\hline 6-month JIBAR yield & 7 & 12-month JIBAR yield & 7 & Overnight FX rate & 5 \\
\hline Overnight FX rate & 8 & 3-month Call deposit index & 8 & $\mathrm{R} 157$ & 5 \\
\hline $\mathrm{R} 157$ & 8 & 6-month Call deposit index & 8 & $\mathrm{R} 186$ & 5 \\
\hline $\mathrm{R} 186$ & 8 & $\mathrm{R} 157$ & 8 & Rand overnight deposit rate & 5 \\
\hline Rand overnight deposit rate & 8 & $\mathrm{R} 186$ & 8 & 3-month JIBAR yield & 5 \\
\hline 3-month JIBAR yield & 8 & Rand overnight deposit rate & 8 & 6-month JIBAR yield & 5 \\
\hline 12-month JIBAR yield & 8 & 3-month JIBAR yield & 8 & 12-month JIBAR yield & 5 \\
\hline 3-month NCD rate & 8 & 6-month JIBAR yield & 8 & 3-month NCD rate & 5 \\
\hline 6-month NCD rate & 8 & 3-month NCD rate & 8 & 6-month NCD rate & 5 \\
\hline 12-month NCD rate & 8 & 6-month NCD rate & 8 & 12-month NCD rate & 5 \\
\hline 3-month T-Bill rate & 8 & 3-month T-Bill rate & 8 & 3-month T-Bill rate & 5 \\
\hline SABOR rate & 8 & SABOR rate & 8 & SABOR rate & 5 \\
\hline R203 & 8 & R203 & 8 & R203 & 5 \\
\hline $\mathrm{R} 204$ & 8 & R204 & 8 & R204 & 5 \\
\hline
\end{tabular}

Source: Compiled by author.

Note: Equal weights were assigned to upside and downside potential in the estimation of the Omega ratio. The geometric return of the 1-to-3year bond index over the horizon under evaluation was assigned as the threshold to estimate the static Omega ratios for the pre- and during financial crisis periods, respectively. The geometric return of the 3-to-7-year bond index over the horizon under evaluation was assigned as the threshold to estimate the static Omega ratios for the post-financial crisis period.

The next prerequisite that was evaluated included determining if the risk-free rate proxies under evaluation moved in tandem with the market (with the JSE All Share index as the equity market proxy), which was accomplished by consulting the annualised covariance. From Table 5 to 7 it is evident that the money market proxies dominated the top three rankings during the pre- and during financial crisis periods. The 6-month JIBAR rate and the 12-month JIBAR rate exhibited the smallest covariance during the pre- and during financial crisis periods. However, the capital market proxies dominated the top two rankings (R157 \& R186, respectively) during the post-financial crisis, but were followed by the 12-month NCD rate as the best performing money market proxy. The most favourite riskfree rate proxies recommended by past studies, which entail the R157 and the 3-month T-Bill rate, did not perform well in terms of covariance during the pre- and during financial crisis periods. The R157 ranked $4^{\text {th }}$ and $14^{\text {th }}$, respectively, whereas the 3 -month T-Bill rate ranked $8^{\text {th }}, 9^{\text {th }}$ and $10^{\text {th }}$ during the pre-, during and post-financial crisis periods, respectively. It is also interesting to note that all the risk-free rate proxies under evaluation exhibited some level of covariance, but the presence of covariance was too small to report in Table A to D in the Appendix.

In addition to having no covariance with the market as a prerequisite, Sharpe (1964) also argued that risk-free assets should have no variation in their returns. To test this prerequisite this paper consulted the Exponential-Weighted Moving Average (EWMA) model to estimate the level of volatility during all three time periods under evaluation. From Table 5 to 7 it is evident that the money market proxies under evaluation dominated the top two rankings during all three time periods under evaluation. The Rand overnight deposit index (ranked $1^{\text {st }}$ ) and the SABOR rate (ranked $2^{\text {nd }}$ ) exhibited the least volatility over all three time periods. The money market proxies also dominated the $3^{\text {rd }}$ position on the rankings of least volatility, with the 3 -month T-Bill rate dominating during the financial crisis period and the 3-month Call deposit index during the post-financial crisis period. The only exception is during the pre-financial crisis period where a capital market proxy (R186) attained the $3^{\text {rd }}$ position. Overall, there were no regularities over the different time periods, therefore, confirming the presence of variation and instability in the returns of the risk-free rate proxies under evaluation. Poor performance in terms of volatility is also observable for the more favourable risk-free proxies recommended by past studies (R157 \& 3-month T-Bill rate). The 3-month T- 
Bill rate performed relatively better compared to the R157, attaining a $4^{\text {th }}$ place during the pre-financial crisis period and a $6^{\text {th }}$ place as its lowest ranking over all three time periods. The R157, on the other hand, ranked $9^{\text {th }}, 11^{\text {th }}$ and $17^{\text {th }}$ over the pre-, during and post-financial crisis periods, respectively, making it the least favourite in terms of volatility. High volatility was also observable in the case of the bond indices, especially for the over 12-year bond index, which performed the worst of all the risk-free rate proxies over all three time periods under evaluation (see Table 5 to 7$)$.

To extend the measurement of risk present in the risk-free rate proxies under evaluation, this paper also consulted upside and downside risk, maximum drawdown, deviation in the maximum drawdown, and the deviation in the maximum upturn. The first observation that can be derived from the results reported by Table 5 to 7 is that all the risk-free rate proxies under evaluation obtained some level risk, which emphasises the argument of Brigham and Ehrhardt (2005) and Ray (2012), which disagreed with assumption of the existence of a risk-free rate. The only exception was in terms of downside risk, where the bond indices did not exhibit any level of downside risk over the three periods under evaluation. This exception also included the 6-month Call deposit index in the pre-financial crisis period. From Table 5 to 7 it is also evident that there are no regularities between the different risk measures over the three time periods under evaluation, thus making it difficult to derive a final conclusion as to which riskfree rate proxy can be considered as the most ideal in terms of the least risk. In order to overcome this problem, equal weights were assigned to the different risk measures in order to derive an overall risk ranking, as reported by Table 5 to 7 . The results from Table 5 to 7 report that the money market proxies under evaluation dominated the top three rankings of the least risk over the pre- and post-financial crisis periods. The 3-month NCD rate was the best performing proxy, followed by the 3-month T-Bill rate and the 6-month NCD rate during the pre-financial crisis period. This ranking, however, differ if volatility is included as an additional risk measure, where the 3-month T-Bill rate performed the best, followed by the 3-month NCD rate and the SABOR rate. During the post-financial crisis period the 3-month NCD rate and the SABOR rate ranked the best, whereas the 3-month T-Bill rate ranked $3^{\text {rd }}$, but was replaced by the Rand overnight deposit rate if volatility was included as an additional risk measure. This observation, however, changed during the financial crisis period, where capital market proxies exhibited better performance in term of lower risk. The R186, SABOR rate, and the R157 were the best performing proxies with the least risk, but by including volatility as an additional risk measure the SABOR rate, 3-month NCD rate, and the Rand overnight deposit index were the best performing proxies. The bond indices, on the other hand, were again the worst performing risk-free rate proxies, where the over-12-year bond index ranked last. 
Table 5. Summary of the overall rankings to determine the most ideal risk-free rate proxy in the pre-financial crisis period

\begin{tabular}{|c|c|c|}
\hline \multicolumn{3}{|c|}{$\begin{array}{l}\text { PRE-FINANCIAL CRISIS PERIOD (Ranked from best to worst) } \\
\end{array}$} \\
\hline Covariance with equity market proxy & Volatility (EWMA) & Risk ranking, excluding volatility \\
\hline 6-month JIBAR yield & Rand overnight deposit rate & 3-month NCD rate \\
\hline 6-month Call deposit index & SABOR rate & 3-month T-Bill rate \\
\hline 3-month Call deposit index & R186 & 6-month NCD rate \\
\hline $\mathrm{R} 157$ & 3-month T-Bill rate & 12-month NCD rate \\
\hline R186 & 3-month Call deposit index & 3-month JIBAR yield \\
\hline R204 & Overnight FX rate & R204 \\
\hline R203 & $\mathrm{R} 204$ & SABOR rate \\
\hline 3-month T-Bill rate & R203 & $\mathrm{R} 157$ \\
\hline Rand overnight deposit rate & $\mathrm{R} 157$ & R203 \\
\hline 12-month JIBAR yield & 6-month Call deposit index & $\mathrm{R} 186$ \\
\hline 6-month NCD rate & 3-month JIBAR yield & Rand overnight deposit rate \\
\hline 3-month NCD rate & 12-month Call deposit index & 12-month JIBAR yield \\
\hline 3-month JIBAR yield & 3-month NCD rate & Overnight FX rate \\
\hline 12-month NCD rate & 6-month NCD rate & 3-month Call deposit index \\
\hline Overnight FX rate & 12-month NCD rate & 12-month Call deposit index \\
\hline SABOR rate & 12-month JIBAR yield & 6-month Call deposit index \\
\hline 12-month Call deposit index & 1-to-3-year bond index & 1-to-3-year bond index \\
\hline 1-to-3-year bond index & 3-to-7-year bond index & 3-to-7-year bond index \\
\hline 3-to-7-year bond index & 6-month JIBAR yield & 7-to12-year bond index \\
\hline 7-to12-year bond index & 7-to12-year bond index & 6-month JIBAR yield \\
\hline Over-12-year bond index & Over-12-year bond index & Over-12-year bond index \\
\hline Risk ranking, including volatility & $\begin{array}{c}\text { Ranking Performance (based on } \\
\text { geometric returns \& static Omega) }\end{array}$ & $\begin{array}{r}\text { Overall ideal } \\
\end{array}$ \\
\hline 3-month T-Bill rate & 6-month JIBAR yield & 3-month T-Bill rate \\
\hline 3-month NCD rate & $\mathrm{R} 157$ & $\mathrm{R} 157$ \\
\hline SABOR rate & R203 & R204 \\
\hline 6-month NCD rate & $\mathrm{R} 204$ & $\mathrm{R} 186$ \\
\hline R186 & 12-month JIBAR yield & R203 \\
\hline 12-month NCD rate & 12-month Call deposit index & 3-month NCD rate \\
\hline R204 & 12-month NCD rate & 6-month NCD rate \\
\hline Rand overnight deposit rate & R186 & 12-month NCD rate \\
\hline 3-month JIBAR yield & 3-month Call deposit index & 3-month JIBAR yield \\
\hline R157 & 6-month Call deposit index & Rand overnight deposit rate \\
\hline R203 & 6-month NCD rate & SABOR rate \\
\hline Overnight FX rate & 3-month NCD rate & 3-month Call deposit index \\
\hline 12-month JIBAR yield & 3-month JIBAR yield & 12-month JIBAR yield \\
\hline 3-month Call deposit index & Overnight FX rate & Overnight FX rate \\
\hline 12-month Call deposit index & Over-12-year bond index & 6-month Call deposit index \\
\hline 6-month Call deposit index & 3-month T-Bill rate & 12-month Call deposit index \\
\hline 1-to-3-year bond index & 7-to12-year bond index & 6-month JIBAR yield \\
\hline 3-to-7-year bond index & Rand overnight deposit rate & 1-to-3-year bond index \\
\hline 7-to12-year bond index & 1-to-3-year bond index & 3-to-7-year bond index \\
\hline 6-month JIBAR yield & SABOR rate & 7-to12-year bond index \\
\hline Over-12-year bond index & 3-to-7-year bond index & Over-12-year bond index \\
\hline
\end{tabular}


Table 6. Summary of the overall rankings to determine the most ideal risk-free rate proxy during the financial crisis period

\begin{tabular}{l|l|l}
\hline \multicolumn{2}{c}{ DURING FINANCIAL CRISIS PERIOD (Ranked from best to worst) } \\
\hline Covariance with equity market proxy & \multicolumn{1}{c}{ Volatility (EWMA) } & \multicolumn{1}{c}{ Risk ranking, excluding volatility } \\
\hline 12-month JIBAR yield & Rand overnight deposit rate & R186 \\
\hline 3-month NCD rate & SABOR rate & SABOR rate \\
\hline 6-month JIBAR yield & 3-month T-Bill rate & R157 \\
\hline 12-month NCD rate & 3-month NCD rate & 3-month NCD rate \\
\hline 3-month JIBAR yield & 3-month JIBAR yield & R203 \\
\hline 6-month NCD rate & 3-month Call deposit index & R204 \\
\hline Overnight FX rate & Overnight FX rate & 3-month JIBAR yield \\
\hline SABOR rate & 6-month NCD rate & 3-month T-Bill rate \\
\hline 3-month T-Bill rate & 6-month JIBAR yield & 6-month NCD rate \\
\hline 3-month Call deposit index & 6-month Call deposit index & 12-month NCD rate \\
\hline Rand overnight deposit rate & R 157 & 6-month JIBAR yield \\
\hline 6-month Call deposit index & 12-month NCD rate & 12-month JIBAR yield \\
\hline 12-month Call deposit index & 12-month JIBAR yield & Rand overnight deposit rate \\
\hline R 157 & R 203 & Overnight FX rate \\
\hline R 186 & R 204 & 12-month Call deposit index \\
\hline R 203 & R 186 & 6-month Call deposit index \\
\hline R 204 & 12-month Call deposit index & 3-month Call deposit index \\
\hline 3-to-7-year bond index & 1-to-3-year bond index & 1-to-3-year bond index \\
\hline 1-to-3-year bond index & 3-to-7-year bond index & 7-to12-year bond index \\
\hline 7-to12-year bond index & 7-to12-year bond index & 3-to-7-year bond index \\
\hline Over-12-year bond index & Over-12-year bond index & Over-12-year bond index \\
\hline & & \\
\hline
\end{tabular}

Risk ranking, including volatility

SABOR rate

3-month NCD rate

R157

R186

3-month JIBAR yield

3-month T-Bill rate

R203

R204

6-month NCD rate

Rand overnight deposit rate

6-month JIBAR yield

12-month NCD rate

Overnight FX rate

12-month JIBAR yield

6-month Call deposit index

3-month Call deposit index

12-month Call deposit index

1-to-3-year bond index

7-to12-year bond index

3-to-7-year bond index

Over-12-year bond index

Source: Compiled by author.

Note: The "Overall ideal" ranking was established by assigning equal weights to covariance, volatility (EWMA), to the different alternative risk

measures, to the geometric returns, and to the static Omega rankings.
Ranking Performance (based on geometric returns \& static Omega)

12-month Call deposit index

12-month JIBAR yield

12-month NCD rate

Overnight FX rate

6-month JIBAR yield

6-month NCD rate

3-month JIBAR yield

3-month NCD rate

6-month Call deposit index

3-month Call deposit index

3-to-7-year bond index

SABOR rate

Rand overnight deposit rate

1-to-3-year bond index

3-month T-Bill rate

R203

R204

7-to12-year bond index

R157

Over-12-year bond index

R186

\section{Overall ideal}

3-month NCD rate

SABOR rate

3-month JIBAR yield

6-month NCD rate

3-month T-Bill rate

R157

12-month NCD rate

6-month JIBAR yield

R186

12-month JIBAR yield

R203

Overnight $\mathrm{FX}$ rate

R204

Rand overnight deposit rate

12-month Call deposit index

3-month Call deposit index

6-month Call deposit index

1-to-3-year bond index

7-to12-year bond index

3-to-7-year bond index

Over-12-year bond index 
Table 7. Summary of the overall rankings to determine the most ideal risk-free rate proxy in the post-financial crisis period

\begin{tabular}{l|l|l}
\hline \multicolumn{2}{c}{ POST-FINANCIAL CRISIS PERIOD (Ranked from best to worst) } \\
\hline Covariance with equity market proxy & \multicolumn{1}{c}{ Volatility (EWMA) } & \multicolumn{1}{c}{ Risk ranking, excluding volatility } \\
\hline R157 & Rand overnight deposit rate & 3-month NCD rate \\
\hline R186 & SABOR rate & SABOR rate \\
\hline 12-month NCD rate & 3-month Call deposit index & 3-month T-Bill rate \\
\hline 12-month JIBAR yield & Overnight FX rate & Rand overnight deposit rate \\
\hline 6-month NCD rate & 3-month JIBAR yield & 6-month NCD rate \\
\hline 12-month Call deposit index & 3-month T-Bill rate & 3-month JIBAR yield \\
\hline Overnight FX rate & 3-month NCD rate & 6-month JIBAR yield \\
\hline 6-month JIBAR yield & 6-month Call deposit index & 12-month NCD rate \\
\hline 3-month NCD rate & 12-month Call deposit index & R186 \\
\hline 3-month T-Bill rate & 6-month JIBAR yield & 12-month JIBAR yield \\
\hline 6-month Call deposit index & 6-month NCD rate & Overnight FX rate \\
\hline 3-month JIBAR yield & R 157 & R157 \\
\hline 3-month Call deposit index & 12-month NCD rate & R204 \\
\hline SABOR rate & 12-month JIBAR yield & R203 \\
\hline Rand overnight deposit rate & R 203 & 3-month Call deposit index \\
\hline R203 & R 204 & 6-month Call deposit index \\
\hline R204 & R 186 & 12-month Call deposit index \\
\hline 1-to-3-year bond index & 1-to-3-year bond index & 1-to-3-year bond index \\
\hline 3-to-7-year bond index & 3-to-7-year bond index & 3-to-7-year bond index \\
\hline 7-to12-year bond index & 7-to12-year bond index & 7-to12-year bond index \\
\hline Over-12-year bond index & Over-12-year bond index & Over-12-year bond index \\
\hline
\end{tabular}

\section{Risk ranking, including volatility}

\section{SABOR rate}

3-month NCD rate

Rand overnight deposit rate

3-month T-Bill rate

6-month NCD rate

3-month JIBAR yield

6-month JIBAR yield

12-month NCD rate

12-month JIBAR yield

Overnight FX rate

R186

3-month Call deposit index

R157

R204

R203

6-month Call deposit index

12-month Call deposit index

1-to-3-year bond index

3-to-7-year bond index

7-to12-year bond index

Over-12-year bond index

Source: Compiled by author.

Note: The "Overall ideal" ranking was established by assigning equal weights to covariance, volatility (EWMA), to the different alternative risk measures, to the geometric returns, and to the static Omega rankings.

From the overall results reported by Table 5 to 7 , it is interesting to note that the business cycle could also have been utilised as an indicator to determine the most ideal risk-free rate proxy. During the economic downswing (represented by the financial crisis period) government bonds were found to be the more preferred selection (lower overall risk), whereas money market proxies (especially the 3-month T-Bill rate and 3-month NCD rate) exhibited more dominance in terms of lower overall risk during the economic upswing phases (represented by the pre- $\&$ post-

\author{
3-month NCD rate \\ 3-month T-Bill rate \\ 6-month NCD rate \\ SABOR rate \\ Rand overnight deposit rate \\ 6-month JIBAR yield \\ 2-month NCD rate \\ R157 \\ Overnight FX rate \\ R204 \\ R203 \\ 12-month Call deposit index \\ 3-month Call deposit index \\ 6-month Call deposit index \\ 1-to-3-year bond index \\ 3-to-7-year bond index \\ 7-to12-year bond index \\ Over-12-year bond index
}


financial crisis periods) under evaluation. These findings motivate the need for future studies to determine if the same conclusion can be made for other financial and economic crisis events, as the findings from this paper contradict one of the characteristics of a risk-free rate asset, which states that risk-free assets should not be influenced by economic events (see Harrington, 1987).

In order to conclude the risk evaluation process, this paper also included price risk to further evaluate the reliability of the fixed coupon government bonds. The estimations of the bond price sensitivity with a change of 100 basis points were used as the price risk proxy for each government bond (see Equation 16), after which price risk was assigned the same weight as the other risk measures in order to generate the "Overall ideal government bond" ranking. From the results reported by Table 8 it is evident that R157 (ranked $1^{\text {st }}$ ) and R186 (ranked $2^{\text {nd }}$ ) was the government bond with the lowest price risk over the three time periods under evaluation, respectively. The "Overall ideal government bond" rankings also confirmed the creditability of previous studies who recommended the use of the R157. However, as the R157 already matured on 15 September 2014, the R186 will be a suitable replacement, followed by R203 and R204, respectively, based on the limited proxies evaluated in this paper.

Table 8. Summary of overall rankings of the government bonds under evaluation (including price risk to establish the overall ideal government bond ranking)

PRE-FINANCIAL CRISIS PERIOD (Ranked from best to worst)

\begin{tabular}{|c|c|c|}
\hline $\begin{array}{c}\text { Overall ideal } \\
\text { (includes all previous measures) }\end{array}$ & Price risk ranking & Overall ideal government bond \\
\hline $\mathrm{R} 157$ & R157 & R157 \\
\hline $\mathrm{R} 186$ & $\mathrm{R} 186$ & $\mathrm{R} 186$ \\
\hline R203 & R203 & R204 \\
\hline $\mathrm{R} 204$ & R204 & $\mathrm{R} 203$ \\
\hline \multicolumn{3}{|c|}{ POST-FINANCIAL CRISIS PERIOD (Ranked from best to worst) } \\
\hline $\begin{array}{c}\text { Overall ideal } \\
\text { (includes all previous measures) }\end{array}$ & Price risk ranking & Overall ideal government bond \\
\hline $\mathrm{R} 157$ & R157 & R157 \\
\hline R186 & R186 & R186 \\
\hline R203 & R203 & $\mathrm{R} 203$ \\
\hline R204 & R204 & R204 \\
\hline \multicolumn{3}{|c|}{ DURING FINANCIAL CRISIS PERIOD (Ranked from best to worst) } \\
\hline $\begin{array}{c}\text { Overall ideal } \\
\text { (includes all previous measures) }\end{array}$ & Price risk ranking & Overall ideal government bond \\
\hline R157 & R157 & R157 \\
\hline $\mathrm{R} 186$ & R186 & $\mathrm{R} 186$ \\
\hline R203 & R203 & R203 \\
\hline R204 & R204 & R204 \\
\hline
\end{tabular}

Source: Compiled by author.

Note: The "Overall ideal government bond" ranking was established by assigning equal weights to covariance, volatility (EWMA), to the different alternative risk measures, to the geometric returns, and to the static Omega rankings. The "Overall ideal" ranking was also determined by including price risk and by assigning the same weight to price risk as the previous risk and performance measures used to determine the previous overall ideal rankings.

From all the findings above it was possible to generate an "Overall ideal" ranking to determine the most suitable risk-free rate proxy for the three time periods under evaluation. However, as there were no regularities found in the results, this paper assigned equal weights to covariance, volatility (EWMA), to the different alternative risk measures (excluding price risk, as this was only applicable to government bonds), to the geometric returns, and to the static Omega rankings, in order to be able to derive a conclusive answer. From Table 5 to 7 it was evident that the most ideal risk-free rate proxies were the 3-month T-Bill rate, the government bonds (R157, R204, R186, R203, respectively) and the 3-month NCD rate for the pre-financial crisis period. However, during the financial crisis period the money market proxies dominated more, where the 3-month NCD rate, SABOR rate, 3-month JIBAR yield, 6-month NCD rate, and 3-month T-Bill rate attained the top five rankings, respectively. The same observation could also be made for the post-financial crisis period, in terms of the money market proxies, where the 3-month NCD rate, 3-month T-Bill rate, 6-month NCD rate, SABOR rate, and Rand overnight deposit rate were the top five 
overall performers, respectively. The same performance was, however, not observable for the top performing capital market proxy (R157, based on Table 8), as it decreased in rankings from $6^{\text {th }}$ place during the financial crisis period to $11^{\text {th }}$ place during the post-financial crisis period. The results reported by Table 5 to 7 also concluded that the bond indices exhibited the worst overall performance, ranking the over-12-year bond index as the worst risk-free rate proxy to consider.

This leads to the final step of the empirical analysis, as all of the risk measures reported above are limited to a static perspective. To overcome this shortcoming this paper introduces a 100 -week rolling Omega ratio as a unique risk stability measure, which has the ability to illustrate how risk evolved over time. To demonstrate this dynamic approach, this paper estimated a 100-week rolling Omega for the over-12-year bond (Figure 1) and 7-to-12-year bond (Figure 2) index, which were the two lowest ranked proxies based on the results reported by Table 5 to 7 . From the figures it is apparent that the over-12-year bond and 7-to-12-year bond indices exhibited a significant level of risk, which also varied over the three time periods under evaluation. These findings emphasised the results already reported by Table 5 to 7 and further justified the unreliability of these two indices as suitable risk-free rate proxies. This variation in risk, as illustrated by Figure 1 and 2, can also be converted into Table 9, which reports only the substantial increases and decreases in risk over the three time periods under evaluation. From the results reported by Table 9, it is interesting to note that there was already a substantial increase in risk before Lehman Brothers Holdings Incorporated filed for bankruptcy on 15 September 2008. Furthermore, although, the 7-to-12-year bond index exhibited a small recovery at the beginning of June 2008, both indices exhibited a further increase in risk by the end of November 2008, which accentuates the beginning of the devastating effects of the global financial crisis. However, the indices did exhibit a significant level of recovery during segments of 2010, 2011 and by end of June 2013, but by the end of August 2014 the over-12-year bond index exhibited another significant increase in risk, which can be assigned to the aftereffects of the Euro crisis, and the political unrest and financial uncertainty in the South African markets. Overall, these results accentuate the benefit and applicability of applying such a dynamic approach, which can assist investors and financial analysts in evaluating the evolving risk of an investment, portfolio or hedge fund.

Figure 1. The rolling Omega of the over-12-year bond index

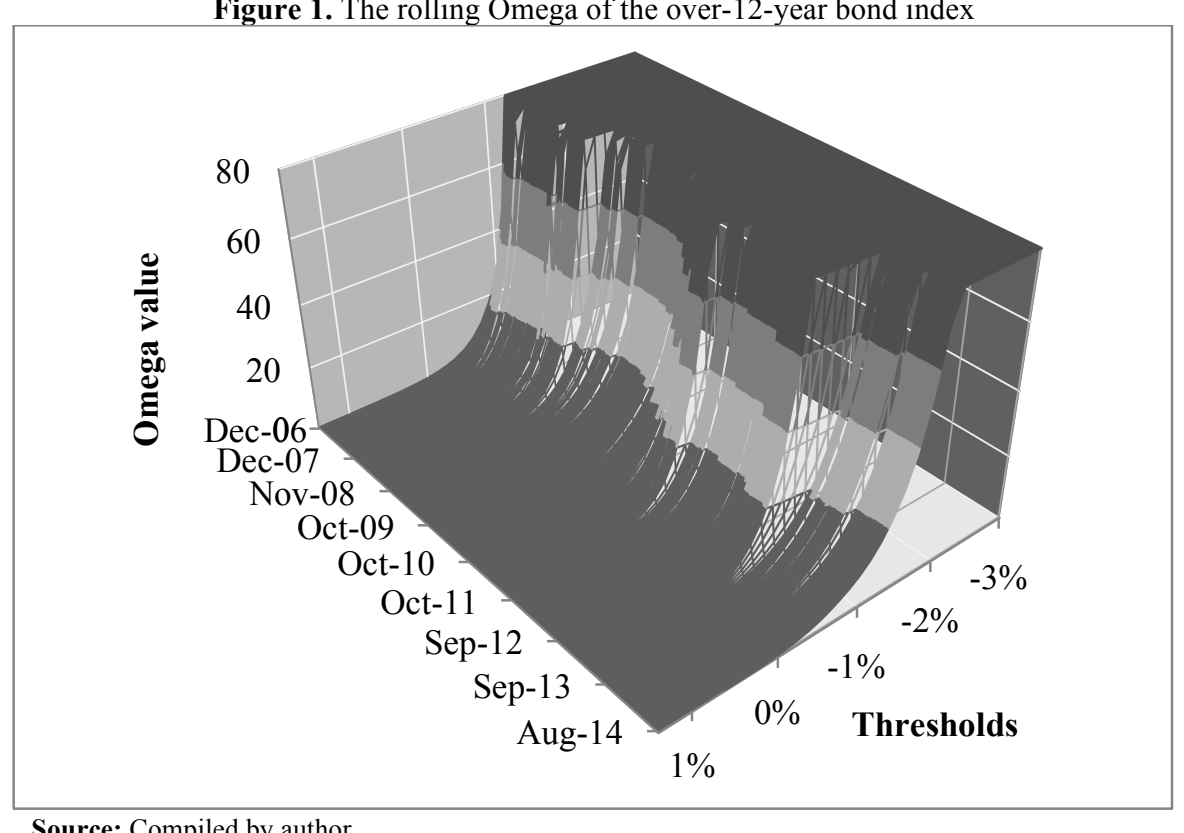

Source: Compiled by author. 
Figure 2. The rolling Omega of the 7-to-12-year bond index

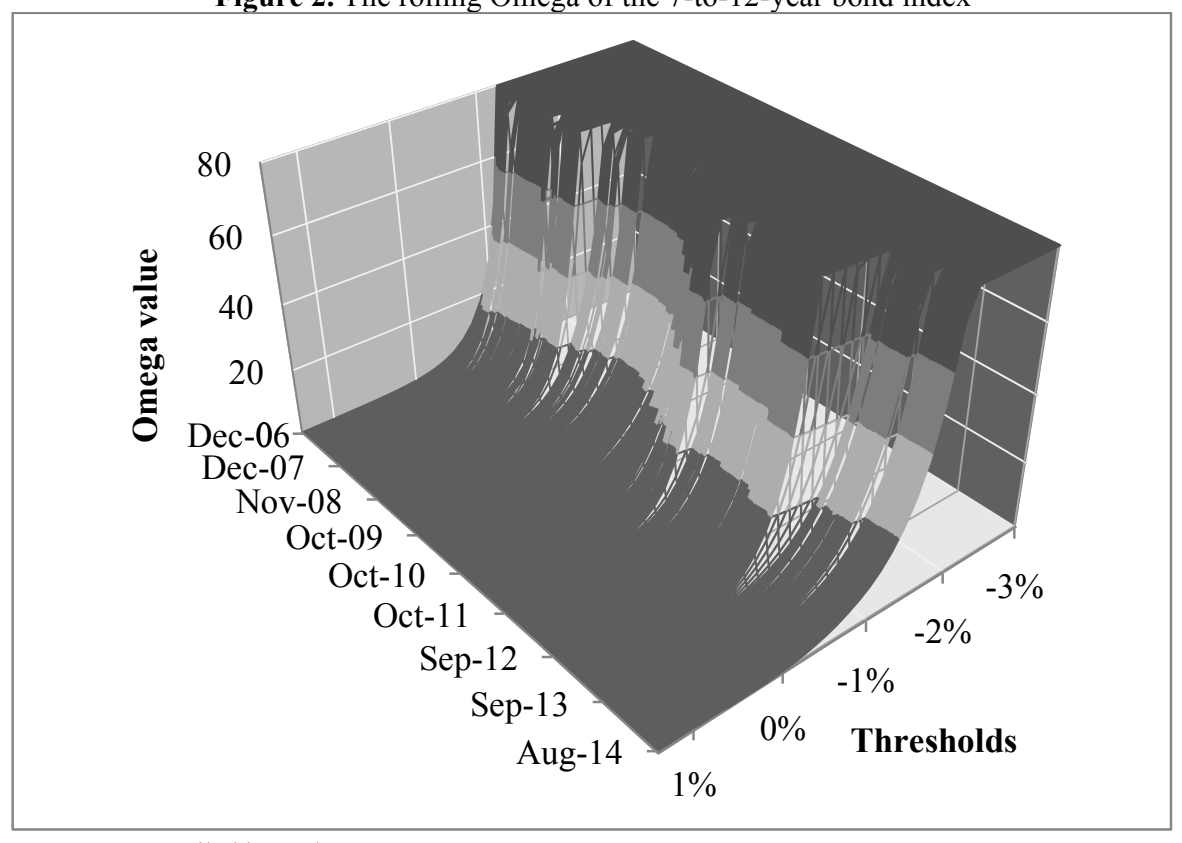

Source: Compiled by author.

Table 9. Summary of the rolling Omega for the over-12-year bond and 7-to-12-year bond indices

(reporting substantial increase and decrease in risk over the three time periods under evaluation)

\begin{tabular}{ll|ll}
\hline \multicolumn{2}{c|}{ OVER 12-YEAR BOND INDEX } & \multicolumn{1}{c}{ 7-TO-12-YEAR BOND INDEX } \\
\hline End of March 2008 & Increase & End of May 2008 & Increase \\
\hline Beginning of November 2008 & Increase & Beginning of June 2008 & Decrease \\
\hline End of August 2010 & Decrease & Beginning of November 2008 & Increase \\
\hline End of December 2010 & Increase & End of December 2010 & Increase \\
\hline Beginning of February 2011 & Decrease & End of April 2011 & Decrease \\
\hline End of January 2013 & Increase & End of September 2011 & Increase \\
\hline End of August 2014 & Increase & End of June 2013 & Decrease \\
\hline
\end{tabular}

Source: Compiled by author.

\section{CONCLUSION AND RECOMMENDATIONS}

The mean-variance Capital Asset Pricing Model (CAPM) requires a risk-free rate in order to estimate the expected returns for an investment or portfolio. This requirement is also applicable for performance measurement and bond pricing, but according to Brigham and Ehrhardt (2005) and Ray (2012) the assumption of the existence of a truly risk-free asset is flawed and deceitful. Also, as there is no consensus of what can be considered as an ideal risk-free rate proxy, the incorrect specification of a risk-free rate can lead to insufficient allocation of scarce resources (Bruner, Eades, Harris \& Higgins, 1998). This led to the goal of this paper, which entailed evaluating how risk-free are some of the South African risk-free rate proxies, and thus determine the ideal risk-free rate proxy to use over a pre-, during and post-financial crisis period.

The results from this paper accentuated the problem of choosing a risk-free rate proxy, as all proxies under evaluation exhibited a certain level of risk, volatile returns, and to some small extent, move in tandem with the market. By consulting the level of volatility, by means of a EWMA model; annualised covariance; and alternative risk measures this paper was able to construct and overall ranking to determine the most ideal risk-free rate proxy. These alternative risk measures entailed upside and downside risk, the maximum drawdown, the deviation in the maximum drawdown, and the deviation in the maximum upturn. From the overall results it was evident that the most ideal risk-free rate proxies was the 3-month T-Bill rate and the 3-month NCD rate over the pre-, during and post-financial crisis periods, respectively. This paper also consulted the level of price risk, after which it was 
established that the R157 was the most ideal capital market proxy to consider, which justified the creditability of previous studies that recommend this proxy. Finally, this paper also demonstrated the applicability of adapting a dynamic approach by consulting a rolling Omega ratio to illustrate how risk evolved over time.

Overall, this paper only provides the first step of establishing a selection process to determine the most ideal riskfree rate proxy. From the results reported in this paper several interesting findings were made which can serve as a motivation for future studies that can refine this process. For example, there was some evidence which endorsed the applicability of the business cycle as an indicator for determining the more ideal risk-free rate proxy. As these findings contradict one of the characteristics of a risk-free rate asset, which states that risk-free assets should not be influenced by economic events (see Harrington, 1987), it will be interesting to evaluate the influence of other financial and economic events on the selection of risk-free rate proxies. It will also be interesting to see how the incorporation of interest rate expectations, the prime rate and the business cycle as leading indicators will assist the selection process and thus improving future investment or portfolio decisions. Another interesting study will be to determine if there is a significant relationship between market efficiency and the choice of risk-free rate proxies, as greater market efficiency will lead to less noise (risk), which can influence the excess returns of an investment or portfolio. Finally, a further investigation is recommended to extent the applicability of more dynamic-based approaches, such as the rolling Omega ratio, in order to overcome the static approach that can limit future investment decisions.

\section{AUTHOR BIOGRAPHY}

Chris van Heerden was appointed as lecturer at the School of Economics, Potchefstroom Campus, North West University after completing his Masters in finance in 2008. Five years after he completed his Ph.D. in finance in 2011, he was promoted to associate-professor and is currently Programme Leader for Economics.

\section{REFERENCES}

Adams, J.F. \& Smith, D.J. (2015). Introduction to fixed-income valuation. (In Petitt, B., Pinto, J.E. \& Pirie, W.L. $3^{\text {rd }}$ Edition. Fixed income analysis, CFA institute investment series. Hoboken, New Jersey: John Wiley \& Sons. pp.91-143).

Allen, J., Hortaçsu, A. \& Kastl, J. (2011). Analyzing default risk and liquidity demand during a financial crisis: The case of Canada. Retrieved from http://www.bankofcanada.ca/wp-content/uploads/2011/08/wp2011-17.pdf.

Amin, G. S. \& Kat, H. M. (2003). Hedge fund performance 1990-2000: Do the "money machines" really add value? Journal of Financial and Quantitative Analysis, 38(2) 251-274.

Anderson, T. W. \& Darling, D. A. (1952). Asymptotic theory of certain "goodness of fit" criteria based on stochastic processes. The Annals of Mathematical Statistics, 23(2) 193-212.

Black, F. (1972). Capital market equilibrium with restricted borrowing. Journal of Business, 45(3) 444-455.

Blake, D. (2000). Financial market analysis. $2^{\text {nd }}$ Edition. New Jersey: Wiley \& Sons.

Bodie, Z., Kane, A. \& Marcus, A.J. (2010). Essentials of investments. $8^{\text {th }}$ Edition. New York: McGraw-Hill/Irwin.

Botha, M. (2007). A comparison of South African hedge fund risk measures. South African Journal of Economics, 75(3) 459477.

Bradfield, D., Barr, G. \& Affleck-Graves, J. (1988). Asset pricing in small markets - the South African case. South African Journal of Business Management, 19(1) 11-21.

Brigham, E. \& Ehrhardt, M. (2005). Financial management: Theory and practice. $12^{\text {th }}$ Edition. Manson, OH: Thomson SouthWestern.

Bruner, R., Eades, K., Harris, R. \& Higgins, R. (1998). Best practices in estimating the cost of capital: Survey and synthesis. Financial Practices and Education, 8(Spring/Summer) 13-28.

Brunnermeier, M.K. (2008). Deciphering the liquidity and credit crunch 2007-08. NBER working paper 14612. Retrieved from http://www.nber.org/papers/w14612.pdf.

Burke, G. (1994). A sharper Sharpe ratio. Futures, 23(3) 56.

Carleton, W. \& Lakonishok, J. (1985). Risk and return on equity: The use of misuse of historical estimates. Financial Analysts Journal, 41(1) 38-47.

Charteris, A. \& Strydom, B. (2011). An examination of the volatility of South African risk-free rate proxies: A component GARCH analysis. Studies in Economics and Econometrics, 35(3) 49-64.

Copeland, T., Koller, T. \& Murrin, J. (2000). Valuation: Measuring and managing the value of companies. $3^{\text {rd }}$ Edition. New York: Wiley.

Correia, C. \& Uliana, E. (2004). Market segmentation and the cost of equity of companies listed on the Johannesburg Stock Exchange. South African Journal of Accounting Research, 18(1) 65-81. 
Cramér, H. (1928). On the composition of elementary errors. Scandinavian Actuarial Journal, (1) 13-74.

Damodaran, A. (2001). Estimating risk-free rates. Retrieved from http://www.bonato.com.ar/Archivos/riskfree.pdf.

De Villiers, P., Lowlings, A., Pettit, T. \& Affleck-Graves, J. (1986). An investigation into the small firm effect on the JSE. South African Journal of Business Management, 17(4) 191-195.

De Wet, J. (2005). EVA versus traditional accounting measures of performance as drivers of shareholders' value - a comparative analysis. Meditari: Research Journal of the School of Accounting Sciences, 13(2) 1-16.

De Wet, R., Krige, J.D., \& Smit, E. vd M. (2008). An investigation into performance rankings of the Omega ratio vs. the Sharpe ratio applied to South African general equity unit trusts. Journal of Studies in Economics and Econometrics, 32(2) 6983.

Eling, M. \& Schuhmacher, F. (2007). Does the choice of performance measure influence the evaluation of hedge funds? Journal of Banking and Finance, 31(9) 2632-2647.

Favre-Bulle, A. \& Pache, S. (2003). The Omega measure: Hedge fund portfolio optimization. Canada: University of Lausanne. (MBF Masters Thesis).

Firer, C. (1993). Estimating the return parameters of the capital asset pricing model. South African Journal of Accounting Research, 7(1) 23-39.

Firer, C., Ross, S., Westerfield, R. \& Jordan, B. (2008). Fundamentals of corporate finance. $4^{\text {th }}$ Edition. Berkshire: McGraw-Hill.

Ghysels, E., Plazzi, A. \& Valkanov, R. (2013). The risk-return relationship and financial crises. Retrieved from http://rady.ucsd.edu/docs/faculty/r_r_revisted_apr_12_2013_eg.pdf.

Giamouridis, D. \& Vrontos, I.D. (2007). Hedge fund portfolio construction: A comparison of static and dynamic approaches. Journal of Banking and Finance, 31(1) 199-217.

Gilli, M., Schumann, E., Di Tollo, G. \& Cabej, G. (2011). Constructing 130/30-portfolios with the Omega ratio. Journal of Asset Management, 12(2) 94-108.

Glosten, L.R., Jagannathan, R. \& Runkle, D.E. (1993). On the relationship between expected value and the volatility of the nominal excess return on stocks. Journal of Finance, 48(5) 1779-1801.

Grandes, M., Peter, M. \& Pinaud, N. (2003). The currency premium and local-currency denominated debt costs in South Africa. OECD development centre. Working paper no.230. Retrieved from http://www.oecd.org/southafrica/23375078.pdf.

Grandes, M. \& Pinaud, N. (2004). Which policies can reduce the cost of capital in Southern Africa? OECD development centre. Working paper no.25. Retrieved from http://www.oecd.org/southafrica/33722694.pdf.

Harlow, W.V. (1991). Asset allocation in a downside-risk framework. Financial Analysts Journal, 47(5) 28-40.

Harrington, D. (1987). Modern portfolio theory, the capital asset pricing model, and arbitrage pricing theory: A user's guide. $2^{\text {nd }}$ Edition. New Jersey: Prentice Hall.

Harrison, P. \& Zhang, H.H. (1999). An investigation of the risk and return relationship at long horizons. The Review of Economics and Statistics, 81(3) 399-408.

Hearn, B. \& Piesse, J. (2009). Modelling stock returns in Southern Africa's equity markets. Journal for Studies in Economics and Econometrics, 33(1) 41-58.

IBM (International Business Machines Corporation). (2013). SPPS Statistics, version 22 program.

INET BFA. (2015). Date source. Retrieved from http://secure.mcgbfa.com/.

Inoue, A. (2001). Testing for distributional change in time series. Econometric Theory, 17(1) 156-187.

Jarque, C.M. \& Bera, A.K. (1987). A test for normality of observations and regression residuals. International Statistical Review, 55(2) $163-172$.

J.P. Morgan/Reuters. (1996). RiskMetrics ${ }^{T M}-$ Technical Document. $4^{\text {th }}$ Edition. Retrieved from http://gloriamundi.com/UploadFile/2010-2/rmtd.pdf.

Kat, H.M. (2003). 10 Things investors should know about hedge funds. The Journal of Wealth Management, 5(4) 72-81.

Keating, C. \& Shadwick, W.F. (2002). A universal performance measure. Journal of Performance Measurement, 6(3) 59-84.

Koch, T. W. \& Macdonald, S. S. (2003). Bank management. $5^{\text {th }}$ Edition. London: Dryden Press.

Kolmogorov, A. N. (1933). Sulla determinazione empirica di une legge di distribuzione. Gior-nale dell'Intituto Italiano degli Attuari, 4:83-91.

Lamm, R. M. (2003). Asymmetric returns and optimal hedge fund portfolios. Journal of Alternative Investments, 6(2) 9-21.

Lintner, J. (1965). The valuation of risk assets and the selection of risky investments in stock portfolios and capital budgets. Review of Economics and Statistics, (February) 13-37.

Lo, A.W. (2004). The adaptive market hypothesis. Journal of Portfolio Management, 30(Sept) 15-29.

Markowitz, H. (1952). Portfolio selection. Journal of Finance, 7(1) 77-91.

Mehra, R. \& Prescott, E.C. (1985). The equity premium: A puzzle. Journal of Monetary Economics, 15(2) 145-161.

Misina, M. (2008). Changing investors' risk appetite: Reality or fiction? The European Journal of Finance, 14(6) $489-501$.

Moolman, E. \& Du Toit, C. (2005). An econometric model of the South African stock market. South African Journal of Economic and Management Sciences, 8(1) 77-91.

Msweli-Mbanga, P. \& Mkhize, H. (2007). The risk-adjusted performance of companies with female directors: A South African case. South African Journal of Economic and Management Sciences, 10(2) 207-213.

Nippani, S., Liu, P. \& Schulman, C. (2001). Are treasury securities free of default? Journal of Financial and Quantitative Analysis, 36(2) 251-265. 
Oldham, G. \& Kroeger, J. (2005). Performance, persistence and benchmarks of selected South African unit trusts for the period 1998-2002. South African Journal of Business Management, 36(4) 81-90.

QMS (Quantitative Micro Software). (2009). EViews user guide 1", Quantitative Micro Software.

Ray, S. (2012). A close look into Black-Scholes option pricing model. Journal of Science, 2(4) 172-178.

Reilly, F.K. \& Brown, K.C. (2003). Investment analysis and portfolio management. $7^{\text {th }}$ Edition. Mason, Ohio: Thomson SouthWestern.

Reilly, F.K. \& Brown, K.C. (2006). Investment analysis and portfolio management. $8^{\text {th }}$ Edition. Mason, Ohio: Thomson SouthWestern.

Reschenhofer, E. (1997). Generalization of the Kolmogorov-Smirnov test. Computational Statistics and Data Analysis, 24(4) 433-441.

Rose, P.S. \& Hudgins, S.C. (2010). Bank management and financial services, $8^{\text {th }}$ Edition. Boston: McGraw-Hill.

SARB (South African Reserve Bank). (2015). Data source. Retrieved from https://www.resbank.co.za/Research/Statistics/Pages/OnlineDownloadFacility.aspx.

Samouilhan, N. (2007). The price of risk in the South African equity market. South African Journal of Economics, 75(3) $442-$ 458.

Shapiro, S.S. \& Wilk, M.B. (1965). An analysis of variance test for normality (Complete samples). Biometrika, 52(3/4) 591-611.

Sharpe, W.F. (1964). Capital asset prices: A theory of market equilibrium under conditions of risk. Journal of Finance, 19(3) 425-442.

Sharpe, W.F. (1966). Mutual fund performance. Journal of Business, 39(1) 119-138.

Smirnov, N. (1939). Sur les Ecarts de la Courbe de Distribution Empirique. Recueil Mathematique (Matematiceskii Sbornik), 6(48) 3-26.

Sortino, F.A. \& Van der Meer, R. (1991). Downside risk. Journal of Portfolio Management, 17(4) 27-31.

Taylor, S.J. (1986). Modelling financial time series. London: Wiley.

Van Heerden, C. (2015). The influence of higher moments and non-normality on the Sharpe ratio: A South African perspective. Journal of Applied Business Research, 31(1) 197-220.

Van Heerden, C. \& Van Vuuren, G. (2015). Establishing the relative competitiveness of South African banking shares: A Kalman filter approach. Journal of Applied Business Research, 31(2) 539-571.

Viviers, S., Bosch, J., Smit, E. \& Buijs, A. (2008). The risk-adjusted performance of responsible investment funds in South Africa. Investment Analysts Journal, 37(68) 39-55.

Von Mises, R. (1931). Wahrscheinlichkeitsrechnung und ihre anwendung in der statistik and theoretischen Physik. Deuticke: Leipzig.

Weil, P. (1989). The equity-premium puzzle and the risk-free rate puzzle. Journal of Monetary Economics, 24(3) 401-421.

Young, T.W. (1991). Calmar ratio: A smoother tool. Futures, 20(1) 40. 


\section{APPENDIX}

Table A1: Descriptive statistics and normality tests

\begin{tabular}{|c|c|c|c|c|c|c|c|c|c|c|c|}
\hline \multicolumn{12}{|c|}{ PRE-FINANCIAL CRISIS PERIOD } \\
\hline & $\begin{array}{l}\text { 1-to-3 } \\
\text { year } \\
\text { bond } \\
\text { index }\end{array}$ & $\begin{array}{c}\text { 3-to-7 } \\
\text { year } \\
\text { bond } \\
\text { index }\end{array}$ & $\begin{array}{c}\text { 7-to-12 } \\
\text { year } \\
\text { bond } \\
\text { index }\end{array}$ & $\begin{array}{l}\text { Over- } \\
\text { 12-year } \\
\text { bond } \\
\text { index }\end{array}$ & $\begin{array}{c}\text { 3-month } \\
\text { Call } \\
\text { deposit } \\
\text { index }\end{array}$ & $\begin{array}{l}\text { 6-month } \\
\text { Call } \\
\text { deposit } \\
\text { index }\end{array}$ & $\begin{array}{c}\text { 12- } \\
\text { month } \\
\text { Call } \\
\text { deposit } \\
\text { index }\end{array}$ & $\begin{array}{c}\text { Overnight } \\
\text { FX rate }\end{array}$ & R157 & R186 & $\mathbf{R 2 0 3}$ \\
\hline Mean & $-0.06 \%$ & $-0.07 \%$ & $-0.01 \%$ & $0.01 \%$ & $0.13 \%$ & $0.13 \%$ & $0.14 \%$ & $0.14 \%$ & $0.15 \%$ & $0.14 \%$ & $0.15 \%$ \\
\hline Max. & $0.96 \%$ & $1.37 \%$ & $2.17 \%$ & $2.95 \%$ & $0.49 \%$ & $1.05 \%$ & $1.03 \%$ & $0.17 \%$ & $0.16 \%$ & $0.16 \%$ & $0.16 \%$ \\
\hline Min. & $-0.76 \%$ & $-1.50 \%$ & $-2.02 \%$ & $-2.38 \%$ & $-0.17 \%$ & $-0.58 \%$ & $-1.10 \%$ & $0.12 \%$ & $0.13 \%$ & $0.13 \%$ & $0.13 \%$ \\
\hline Skew. & 0.58 & 0.03 & 0.05 & 0.08 & 1.31 & 2.21 & -3.03 & 1.21 & -0.04 & 0.38 & -0.05 \\
\hline Kurt. & 6.48 & 4.49 & 3.49 & 3.16 & 43.43 & 48.59 & 51.38 & 4.15 & 2.11 & 2.43 & 2.07 \\
\hline JB & $58.09 * *$ & $9.62 * *$ & 1.07 & 0.22 & $>100 * *$ & $>100 * *$ & $>100 * *$ & $31.07 * *$ & 3.44 & 3.93 & 3.79 \\
\hline KS & $0.10^{* *}$ & 0.07 & 0.08 & 0.07 & $0.40 * *$ & $0.45^{* *}$ & $0.47 * *$ & $0.16^{* *}$ & $0.09 * *$ & 0.08 & 0.08 \\
\hline SW & $0.95 * *$ & 0.98 & 0.99 & 0.99 & $0.33 * *$ & $0.23 * *$ & $0.20 * *$ & $0.88 * *$ & $0.96 * *$ & $0.96 * *$ & $0.97 * *$ \\
\hline CVM & $0.17 * *$ & 0.10 & 0.10 & 0.08 & $4.85 * *$ & $6.66^{* *}$ & $7.07 * *$ & $0.67 * *$ & $0.11^{*}$ & $0.15^{* *}$ & 0.09 \\
\hline AD & $1.12 * *$ & 0.59 & 0.59 & 0.48 & $23.93 * *$ & $31.54 * *$ & $33.19 * *$ & $3.93 * *$ & $0.97 * *$ & $1.15 * *$ & $0.85 * *$ \\
\hline
\end{tabular}

\section{DURING FINANCIAL CRISIS PERIOD}

\begin{tabular}{|c|c|c|c|c|c|c|c|c|c|c|c|}
\hline & $\begin{array}{l}\text { 1-to-3 } \\
\text { year } \\
\text { bond } \\
\text { index }\end{array}$ & $\begin{array}{c}\text { 3-to-7 } \\
\text { year } \\
\text { bond } \\
\text { index }\end{array}$ & $\begin{array}{c}\text { 7-to-12 } \\
\text { year } \\
\text { bond } \\
\text { index }\end{array}$ & $\begin{array}{c}\text { Over-12 } \\
\text { year } \\
\text { bond } \\
\text { index }\end{array}$ & $\begin{array}{c}\text { 3-month } \\
\text { Call } \\
\text { deposit } \\
\text { index }\end{array}$ & $\begin{array}{c}\text { 6-month } \\
\text { Call } \\
\text { deposit } \\
\text { index }\end{array}$ & $\begin{array}{c}12- \\
\text { month } \\
\text { Call } \\
\text { deposit } \\
\text { index } \\
\end{array}$ & $\begin{array}{l}\text { Overnight } \\
\text { FX rate }\end{array}$ & R157 & R186 & R203 \\
\hline Mean & $-0.05 \%$ & $-0.04 \%$ & $-0.06 \%$ & $-0.09 \%$ & $0.18 \%$ & $0.18 \%$ & $0.19 \%$ & $0.18 \%$ & $0.16 \%$ & $0.16 \%$ & $0.16 \%$ \\
\hline Max. & $3.50 \%$ & $7.91 \%$ & $4.05 \%$ & $5.77 \%$ & $0.23 \%$ & $0.24 \%$ & $0.26 \%$ & $0.26 \%$ & $0.20 \%$ & $0.19 \%$ & $0.20 \%$ \\
\hline Min. & $-4.91 \%$ & $-6.22 \%$ & $-2.84 \%$ & $-3.69 \%$ & $0.08 \%$ & $0.08 \%$ & $0.08 \%$ & $0.13 \%$ & $0.13 \%$ & $0.13 \%$ & $0.14 \%$ \\
\hline Skew. & -2.25 & 1.59 & 0.76 & 0.68 & -0.43 & -0.39 & -0.60 & -0.05 & 0.92 & 0.21 & 0.48 \\
\hline Kurt. & 42.17 & 23.96 & 5.89 & 5.24 & 2.53 & 2.90 & 4.39 & 2.30 & 4.05 & 2.95 & 3.43 \\
\hline JB & $>100 * *$ & $>100 * *$ & $72.42 * *$ & $46.43 * *$ & $6.52 * *$ & 4.29 & $23.15^{* *}$ & 3.37 & $30.70 * *$ & 1.18 & $7.48 * *$ \\
\hline KS & $0.19 * *$ & $0.20 * *$ & $0.08 * *$ & $0.07 * *$ & $0.11^{* *}$ & $0.07 * *$ & $0.07 * *$ & $0.08 * *$ & $0.12 * *$ & $0.07^{*}$ & 0.06 \\
\hline SW & $0.60 * *$ & $0.71 * *$ & $0.95 * *$ & $0.96^{* *}$ & $0.95 * *$ & $0.97 * *$ & $0.96^{* *}$ & $0.97 * *$ & $0.94 * *$ & $0.97 * *$ & $0.97 * *$ \\
\hline CVM & $2.39 * *$ & $1.98 * *$ & $0.25 * *$ & $0.18 * *$ & $0.28 * *$ & $0.18^{* *}$ & $0.09 * *$ & $0.18^{* *}$ & $0.40 * *$ & $0.13 * *$ & 0.10 \\
\hline AD & $13.48 * *$ & $11.00 * *$ & $1.66 * *$ & $1.23 * *$ & $2.04 * *$ & $1.34 * *$ & $1.03 * *$ & $1.35^{* *}$ & $2.34 * *$ & $1.11^{* *}$ & $0.90 * *$ \\
\hline
\end{tabular}

\section{POST-FINANCIAL CRISIS PERIOD}

\begin{tabular}{|c|c|c|c|c|c|c|c|c|c|c|c|}
\hline & $\begin{array}{c}\text { 1-to-3 } \\
\text { year } \\
\text { bond } \\
\text { index }\end{array}$ & $\begin{array}{c}\text { 3-to-7 } \\
\text { year } \\
\text { bond } \\
\text { index }\end{array}$ & $\begin{array}{c}\text { 7-to-12 } \\
\text { year } \\
\text { bond } \\
\text { index }\end{array}$ & $\begin{array}{c}\text { Over-12 } \\
\text { year } \\
\text { bond } \\
\text { index }\end{array}$ & $\begin{array}{c}\text { 3-month } \\
\text { Call } \\
\text { deposit } \\
\text { index }\end{array}$ & $\begin{array}{c}\text { 6-month } \\
\text { Call } \\
\text { deposit } \\
\text { index }\end{array}$ & $\begin{array}{c}\text { 12- } \\
\text { month } \\
\text { Call } \\
\text { deposit } \\
\text { index }\end{array}$ & $\begin{array}{l}\text { Overnight } \\
\text { FX rate }\end{array}$ & R157 & R186 & R203 \\
\hline Mean & $-0.06 \%$ & $0.00 \%$ & $0.03 \%$ & $0.01 \%$ & $0.10 \%$ & $0.11 \%$ & $0.12 \%$ & $0.10 \%$ & $0.12 \%$ & $0.15 \%$ & $0.14 \%$ \\
\hline Max. & $0.47 \%$ & $1.24 \%$ & $2.15 \%$ & $3.34 \%$ & $0.15 \%$ & $0.16 \%$ & $0.17 \%$ & $0.14 \%$ & $0.16 \%$ & $0.17 \%$ & $0.17 \%$ \\
\hline Min. & $-1.04 \%$ & $-2.18 \%$ & $-2.71 \%$ & $-3.09 \%$ & $0.04 \%$ & $0.04 \%$ & $0.05 \%$ & $0.09 \%$ & $0.09 \%$ & $0.12 \%$ & $0.10 \%$ \\
\hline Kurt. & 6.54 & 5.83 & 4.39 & 3.59 & 6.69 & 6.21 & 4.85 & 3.73 & 2.08 & 2.90 & 2.14 \\
\hline JB & $>100 * *$ & $>100 * *$ & $43.08 * *$ & $5.07 *$ & $>100 * *$ & $>100 * *$ & $38.12 * *$ & $58.16 * *$ & $8.91 * *$ & $13.08 * *$ & $9.01 * *$ \\
\hline KS & $0.10 * *$ & $0.10 * *$ & $0.08 * *$ & $0.08 * *$ & $0.17 * *$ & $0.17 * *$ & $0.16^{* *}$ & $0.16^{* *}$ & $0.08 * *$ & $0.10 * *$ & $0.09 * *$ \\
\hline SW & $0.94 * *$ & $0.94 * *$ & $0.97 * *$ & $0.99 *$ & $0.89 * *$ & $0.90 * *$ & $0.90 * *$ & $0.89 * *$ & $0.97 * *$ & $0.97 * *$ & $0.96 * *$ \\
\hline CVM & $0.58 * *$ & $0.54 * *$ & $0.35^{* *}$ & $0.27 * *$ & $1.64 * *$ & $1.52 * *$ & $1.64 * *$ & $1.43^{* *}$ & $0.20 * *$ & $0.50 * *$ & $0.27 * *$ \\
\hline AD & $3.52 * *$ & $3.35 * *$ & $2.18 * *$ & $1.36 * *$ & $9.14 * *$ & $8.50 * *$ & $9.00 * *$ & $8.49 * *$ & $1.83 * *$ & $2.85 * *$ & $2.41 * *$ \\
\hline
\end{tabular}

Source: Estimated in the EViews 7 program (QMS, 2009) and the IBM ${ }^{\circledR}$ SPPS Statistics, version 22 program (IBM, 2013), respectively.

Note: Skew. denotes skewness; Kurt. denotes kurtosis; JB denotes Jarque-Bera; KS denotes Kolmogorov-Smirnov; SW denotes Shapiro-Wilk; CVM denotes Cramer-von Mises; AD denotes Anderson-Darling

Note: The Marquardt/Quadratic Hill optimisation algorithm was used to estimate the Cramer-von Mises and Anderson-Darling normality tests, respectively.

Note: ** illustrate that the null hypothesis for normality is rejected at the $5 \%$ level of significance; * illustrate that the null hypothesis for normality is rejected at the $10 \%$ level of significance 
Table A2. Descriptive statistics and normality tests

\begin{tabular}{|c|c|c|c|c|c|c|c|c|c|c|}
\hline \multicolumn{11}{|c|}{ PRE-FINANCIAL CRISIS PERIOD } \\
\hline & R204 & $\begin{array}{c}\text { Rand } \\
\text { overnight } \\
\text { deposit } \\
\text { rate }\end{array}$ & $\begin{array}{c}\text { 3-month } \\
\text { JIBAR } \\
\text { yield }\end{array}$ & $\begin{array}{c}\text { 6-month } \\
\text { JIBAR } \\
\text { yield }\end{array}$ & $\begin{array}{c}\text { 12- } \\
\text { month } \\
\text { JIBAR } \\
\text { yield }\end{array}$ & $\begin{array}{c}\text { 3-month } \\
\text { NCD } \\
\text { rate }\end{array}$ & $\begin{array}{c}\text { 6-month } \\
\text { NCD } \\
\text { rate }\end{array}$ & $\begin{array}{c}\text { 12- } \\
\text { month } \\
\text { NCD } \\
\text { rate }\end{array}$ & $\begin{array}{c}\text { 3-month } \\
\text { T-Bill } \\
\text { rate }\end{array}$ & $\begin{array}{c}\text { SABOR } \\
\text { rate }\end{array}$ \\
\hline Mean & $0.15 \%$ & $0.13 \%$ & $0.14 \%$ & $0.19 \%$ & $0.15 \%$ & $0.14 \%$ & $0.14 \%$ & $0.15 \%$ & $0.13 \%$ & $0.13 \%$ \\
\hline Max. & $0.16 \%$ & $0.16 \%$ & $0.17 \%$ & $5.51 \%$ & $0.18 \%$ & $0.17 \%$ & $0.17 \%$ & $0.18 \%$ & $0.16 \%$ & $0.16 \%$ \\
\hline Min. & $0.13 \%$ & $0.10 \%$ & $0.13 \%$ & $0.13 \%$ & $0.13 \%$ & $0.12 \%$ & $0.13 \%$ & $0.13 \%$ & $0.12 \%$ & $0.12 \%$ \\
\hline Kurt. & 2.06 & 4.60 & 3.54 & 101.89 & 2.57 & 3.41 & 3.04 & 2.42 & 3.02 & 3.64 \\
\hline JB & 3.85 & $15.13^{* *}$ & $32.04 * *$ & $>100 * *$ & $20.96 * *$ & $29.01 * *$ & $25.76 * *$ & $19.04^{* *}$ & $22.12 * *$ & $28.27 * *$ \\
\hline KS & 0.07 & $0.25 * *$ & $0.24 * *$ & $0.51 * *$ & $0.26 * *$ & $0.25 * *$ & $0.24 * *$ & $0.26^{* *}$ & $0.24 * *$ & $0.22 * *$ \\
\hline SW & $0.97 * *$ & $0.83 * *$ & $0.77 * *$ & $0.08 * *$ & $0.77 * *$ & $0.78 * *$ & $0.78 * *$ & $0.79 * *$ & $0.81 * *$ & $0.84 * *$ \\
\hline CVM & 0.09 & $1.47 * *$ & $1.68 * *$ & $8.04 * *$ & $1.84 * *$ & $1.62 * *$ & $1.72 * *$ & $1.73 * *$ & $1.34 * *$ & $1.09 * *$ \\
\hline AD & $0.83^{* *}$ & $7.80 * *$ & $9.42 * *$ & $43.90 * *$ & $9.97 * *$ & $9.01 * *$ & $9.40 * *$ & $9.32 * *$ & $7.74 * *$ & $6.10^{* *}$ \\
\hline
\end{tabular}

DURING FINANCIAL CRISIS PERIOD

\begin{tabular}{|c|c|c|c|c|c|c|c|c|c|c|}
\hline & R204 & $\begin{array}{c}\text { Rand } \\
\text { overnight } \\
\text { deposit } \\
\text { rate } \\
\end{array}$ & $\begin{array}{c}\text { 3-month } \\
\text { JIBAR } \\
\text { yield }\end{array}$ & $\begin{array}{c}\text { 6-month } \\
\text { JIBAR } \\
\text { yield }\end{array}$ & $\begin{array}{c}\text { 12- } \\
\text { month } \\
\text { JIBAR } \\
\text { yield }\end{array}$ & $\begin{array}{c}\text { 3-month } \\
\text { NCD } \\
\text { rate }\end{array}$ & $\begin{array}{c}\text { 6-month } \\
\text { NCD } \\
\text { rate }\end{array}$ & $\begin{array}{c}\text { 12- } \\
\text { month } \\
\text { NCD } \\
\text { rate } \\
\end{array}$ & $\begin{array}{c}\text { 3-month } \\
\text { T-Bill } \\
\text { rate }\end{array}$ & $\begin{array}{c}\text { SABOR } \\
\text { rate }\end{array}$ \\
\hline Mean & $0.16 \%$ & $0.17 \%$ & $0.18 \%$ & $0.19 \%$ & $0.19 \%$ & $0.18 \%$ & $0.19 \%$ & $0.19 \%$ & $0.17 \%$ & $0.18 \%$ \\
\hline Max. & $0.20 \%$ & $0.22 \%$ & $0.23 \%$ & $0.24 \%$ & $0.25 \%$ & $0.23 \%$ & $0.24 \%$ & $0.25 \%$ & $0.21 \%$ & $0.22 \%$ \\
\hline Min. & $0.14 \%$ & $0.12 \%$ & $0.13 \%$ & $0.13 \%$ & $0.14 \%$ & $0.13 \%$ & $0.14 \%$ & $0.14 \%$ & $0.13 \%$ & $0.13 \%$ \\
\hline Skew. & 0.43 & -0.35 & -0.30 & -0.13 & 0.14 & -0.31 & -0.13 & 0.16 & -0.19 & -0.35 \\
\hline JB & $5.90 *$ & $12.58 * *$ & $12.42 * *$ & $11.82 * *$ & $11.43 * *$ & $12.66 * *$ & $11.85^{* *}$ & $11.48 * *$ & $12.17 * *$ & $12.16^{* *}$ \\
\hline KS & 0.06 & $0.13 * *$ & $0.13 * *$ & $0.11 * *$ & $0.13 * *$ & $0.14 * *$ & $0.10 * *$ & $0.13 * *$ & $0.13 * *$ & $0.12 * *$ \\
\hline SW & $0.97 * *$ & $0.91 * *$ & $0.92 * *$ & $0.93 * *$ & $0.93 * *$ & $0.91 * *$ & $0.93 * *$ & $0.93 * *$ & $0.93 * *$ & $0.91 * *$ \\
\hline CVM & 0.09 & $0.54 * *$ & $0.52 * *$ & $0.43 * *$ & $0.49 * *$ & $0.53 * *$ & $0.43 * *$ & $0.48 * *$ & $0.53 * *$ & $0.52 * *$ \\
\hline AD & $0.90 * *$ & $4.22 * *$ & $3.90 * *$ & $3.18^{* *}$ & $3.40 * *$ & $4.00 * *$ & $3.19 * *$ & $3.30 * *$ & $3.63 * *$ & $4.07 * *$ \\
\hline
\end{tabular}

\section{POST-FINANCIAL CRISIS PERIOD}

\begin{tabular}{|c|c|c|c|c|c|c|c|c|c|c|}
\hline & R204 & $\begin{array}{c}\text { Rand } \\
\text { overnight } \\
\text { deposit } \\
\text { rate } \\
\end{array}$ & $\begin{array}{c}\text { 3-month } \\
\text { JIBAR } \\
\text { yield }\end{array}$ & $\begin{array}{c}\text { 6-month } \\
\text { JIBAR } \\
\text { yield }\end{array}$ & $\begin{array}{c}\text { 12- } \\
\text { month } \\
\text { JIBAR } \\
\text { yield }\end{array}$ & $\begin{array}{c}\text { 3-month } \\
\text { NCD } \\
\text { rate }\end{array}$ & $\begin{array}{c}\text { 6-month } \\
\text { NCD } \\
\text { rate }\end{array}$ & $\begin{array}{c}\text { 12- } \\
\text { month } \\
\text { NCD } \\
\text { rate }\end{array}$ & $\begin{array}{c}\text { 3-month } \\
\text { T-Bill } \\
\text { rate }\end{array}$ & $\begin{array}{c}\text { SABOR } \\
\text { rate }\end{array}$ \\
\hline Max. & $0.17 \%$ & $0.13 \%$ & $0.13 \%$ & $0.14 \%$ & $0.15 \%$ & $0.13 \%$ & $0.14 \%$ & $0.15 \%$ & $0.13 \%$ & $0.13 \%$ \\
\hline Min. & $0.11 \%$ & $0.09 \%$ & $0.10 \%$ & $0.10 \%$ & $0.10 \%$ & $0.09 \%$ & $0.10 \%$ & $0.10 \%$ & $0.09 \%$ & $0.09 \%$ \\
\hline Skew. & -0.30 & 1.20 & 1.25 & 1.13 & 0.83 & 1.23 & 1.12 & 0.83 & 1.13 & 1.11 \\
\hline JB & $11.10 * *$ & $65.99 * *$ & $75.45 * *$ & $60.88 * *$ & $28.49 * *$ & $73.36 * *$ & $60.82 * *$ & $29.16^{* *}$ & $57.97 * *$ & $54.99 * *$ \\
\hline $\mathbf{K S}$ & $0.10 * *$ & $0.25 * *$ & $0.22 * *$ & $0.23 * *$ & $0.15 * *$ & $0.21 * *$ & $0.21 * *$ & $0.16^{* *}$ & $0.19 * *$ & $0.23 * *$ \\
\hline SW & $0.96^{* *}$ & $0.81 * *$ & $0.83 * *$ & $0.89 * *$ & $0.92 * *$ & $0.83 * *$ & $0.89 * *$ & $0.92 * *$ & $0.87 * *$ & $0.83 * *$ \\
\hline CVM & $0.42 * *$ & $3.08 * *$ & $2.46 * *$ & $1.59 * *$ & $1.17 * *$ & $2.43^{* *}$ & $1.47 * *$ & $1.10^{* *}$ & $1.78 * *$ & $2.63 * *$ \\
\hline AD & $3.15^{* *}$ & $17.64 * *$ & $14.44 * *$ & $8.74 * *$ & $6.51 * *$ & $14.29 * *$ & $8.16^{* *}$ & $6.14^{* *}$ & $10.64^{* *}$ & $15.16 * *$ \\
\hline
\end{tabular}

Source: Estimated in the EViews 7 program (QMS, 2009) and the IBM ${ }^{\circledR}$ SPPS Statistics, version 22 program (IBM, 2013), respectively.

Note: Skew. denotes skewness; Kurt. denotes kurtosis; JB denotes Jarque-Bera; KS denotes Kolmogorov-Smirnov; SW denotes Shapiro-Wilk; CVM denotes Cramer-von Mises; AD denotes Anderson-Darling

Note: The Marquardt/Quadratic Hill optimisation algorithm was used to estimate the Cramer-von Mises and Anderson-Darling normality tests, respectively.

Note: ** illustrate that the null hypothesis for normality is rejected at the $5 \%$ level of significance; * illustrate that the null hypothesis for normality is rejected at the $10 \%$ level of significance 
Table B. Volatility and alternative risk and performance measures $\sim$ Pre-financial crisis period (Ranked from best to worst)

\begin{tabular}{|c|c|c|c|c|c|}
\hline \multicolumn{2}{|c|}{ Annualised EWMA evaluation } & \multicolumn{2}{|c|}{ Annualised standard deviation } & \multicolumn{2}{|c|}{ Maximum drawdown } \\
\hline Rand overnight deposit rate & $1.03 \%$ & R 203 & $0.05 \%$ & 6-month NCD rate & $0.00 \%$ \\
\hline SABOR rate & $1.03 \%$ & R 204 & $0.05 \%$ & 3-month NCD rate & $0.00 \%$ \\
\hline R186 & $1.05 \%$ & R157 & $0.05 \%$ & 12-month NCD rate & $0.00 \%$ \\
\hline 3-month Call deposit index & $1.06 \%$ & 3-month T-Bill rate & $0.07 \%$ & Rand overnight deposit rate & $0.01 \%$ \\
\hline Overnight FX rate & $1.08 \%$ & Rand overnight deposit rate & $0.07 \%$ & 3-month JIBAR yield & $0.01 \%$ \\
\hline R204 & $1.08 \%$ & SABOR rate & $0.07 \%$ & R157 & $0.01 \%$ \\
\hline $\mathrm{R} 157$ & $1.09 \%$ & 3-month JIBAR yield & $0.08 \%$ & R204 & $0.01 \%$ \\
\hline 6-month Call deposit index & $1.11 \%$ & 3-month NCD rate & $0.08 \%$ & 12-month JIBAR yield & $0.01 \%$ \\
\hline 3-month JIBAR yield & $1.11 \%$ & 6-month NCD rate & $0.10 \%$ & SABOR rate & $0.01 \%$ \\
\hline 12-month Call deposit index & $1.11 \%$ & 12-month NCD rate & $0.11 \%$ & $\mathrm{R} 186$ & $0.01 \%$ \\
\hline 3-month NCD rate & $1.11 \%$ & 12-month JIBAR yield & $0.11 \%$ & Overnight $\mathrm{FX}$ rate & $0.04 \%$ \\
\hline 6-month NCD rate & $1.15 \%$ & 3-month Call deposit index & $0.35 \%$ & 3-month Call deposit index & $0.41 \%$ \\
\hline 12-month NCD rate & $1.19 \%$ & 6-month Call deposit index & $0.85 \%$ & 12-month Call deposit index & $0.88 \%$ \\
\hline 1-to-3-year bond index & $1.30 \%$ & 1-to-3-year bond index & $1.68 \%$ & 1-to-3-year bond index & $1.40 \%$ \\
\hline 3-to-7-year bond index & $2.60 \%$ & 3-to-7-year bond index & $3.06 \%$ & 3-to-7-year bond index & $2.07 \%$ \\
\hline 6-month JIBAR yield & $4.34 \%$ & 6-month JIBAR yield & $3.80 \%$ & 7-to-12-year bond index & $3.45 \%$ \\
\hline 7-to-12-year bond index & $4.47 \%$ & 7-to-12-year bond index & $5.29 \%$ & Over-12-year bond index & $4.89 \%$ \\
\hline Over-12-year bond index & $6.50 \%$ & Over-12-year bond index & $7.50 \%$ & 6-month JIBAR yield & $5.37 \%$ \\
\hline \multicolumn{2}{|c|}{ Deviation in maximum drawdown } & \multicolumn{2}{|c|}{ Deviation in maximum upturn } & \multicolumn{2}{|c|}{ Geometric return } \\
\hline 6-month NCD rate & $0.00 \%$ & 3-month NCD rate & $0.00 \%$ & 6-month JIBAR yield & $10.46 \%$ \\
\hline 12-month NCD rate & $0.00 \%$ & 12-month NCD rate & $0.00 \%$ & R157 & $8.02 \%$ \\
\hline 3-month NCD rate & $0.00 \%$ & 3-month T-Bill rate & $0.00 \%$ & R203 & $8.01 \%$ \\
\hline 3-month T-Bill rate & $0.00 \%$ & SABOR rate & $0.00 \%$ & R204 & $7.99 \%$ \\
\hline 3-month JIBAR yield & $0.00 \%$ & 6-month NCD rate & $0.00 \%$ & 12-month JIBAR yield & $7.88 \%$ \\
\hline SABOR rate & $0.00 \%$ & 3-month JIBAR yield & $0.00 \%$ & 12-month NCD rate & $7.88 \%$ \\
\hline R204 & $0.00 \%$ & $\mathrm{R} 186$ & $0.01 \%$ & $\mathrm{R} 186$ & $7.65 \%$ \\
\hline R186 & $0.00 \%$ & $\mathrm{R} 157$ & $0.01 \%$ & 6-month NCD rate & $7.63 \%$ \\
\hline 12-month JIBAR yield & $0.00 \%$ & 12-month JIBAR yield & $0.01 \%$ & 3-month NCD rate & $7.47 \%$ \\
\hline Rand overnight deposit rate & $0.00 \%$ & Rand overnight deposit rate & $0.01 \%$ & Overnight FX rate & $7.39 \%$ \\
\hline Overnight FX rate & $0.01 \%$ & Overnight FX rate & $0.01 \%$ & 6-month Call deposit index & $7.21 \%$ \\
\hline 3-month Call deposit index & $0.12 \%$ & 3-month Call deposit index & $0.07 \%$ & 3-month Call deposit index & $7.16 \%$ \\
\hline 12-month Call deposit index & $0.27 \%$ & 6-month Call deposit index & $0.17 \%$ & 3-month T-Bill rate & $7.13 \%$ \\
\hline 1-to-3-year bond index & $0.27 \%$ & 12-month Call deposit index & $0.27 \%$ & Rand overnight deposit rate & $7.02 \%$ \\
\hline 6-month Call deposit index & $0.28 \%$ & 1-to-3-year bond index & $0.31 \%$ & SABOR rate & $6.96 \%$ \\
\hline 3-to-7-year bond index & $0.44 \%$ & 3-to-7-year bond index & $0.52 \%$ & Over-12-year bond index & $0.31 \%$ \\
\hline 7-to-12-year bond index & $0.72 \%$ & 7-to-12-year bond index & $0.89 \%$ & 7-to-12-year bond index & $-0.44 \%$ \\
\hline Over-12-year bond index & $1.04 \%$ & Over-12-year bond index & $1.15 \%$ & 1-to-3-year bond index & $-3.05 \%$ \\
\hline 6-month JIBAR yield & $1.55 \%$ & 6-month JIBAR yield & $1.44 \%$ & 3-to-7-year bond index & $-3.48 \%$ \\
\hline
\end{tabular}


(Table B continued)

\begin{tabular}{|c|c|c|c|c|c|}
\hline \multicolumn{2}{|c|}{ Downside risk } & \multicolumn{2}{|l|}{ Upside risk } & \multicolumn{2}{|c|}{$\begin{array}{c}\text { Annualised covariance } \\
\text { with equity market proxy }\end{array}$} \\
\hline 3-month Call deposit index & $0.000 \%$ & R 203 & $0.05 \%$ & 6-month JIBAR yield & $0.00 \%$ \\
\hline 12-month Call deposit index & $0.000 \%$ & R 204 & $0.05 \%$ & 6-month Call deposit index & $0.00 \%$ \\
\hline Overnight FX rate & $0.000 \%$ & $\mathrm{R} 157$ & $0.05 \%$ & 3-month Call deposit index & $0.00 \%$ \\
\hline R157 & $0.000 \%$ & $\mathrm{R} 186$ & $0.06 \%$ & R157 & $0.00 \%$ \\
\hline R186 & $0.000 \%$ & 3-month T-Bill rate & $0.07 \%$ & R186 & $0.00 \%$ \\
\hline R203 & $0.000 \%$ & Rand overnight deposit rate & $0.07 \%$ & R204 & $0.00 \%$ \\
\hline R204 & $0.000 \%$ & SABOR rate & $0.07 \%$ & R203 & $0.00 \%$ \\
\hline Rand overnight deposit rate & $0.000 \%$ & Overnight FX rate & $0.08 \%$ & 3-month T-Bill rate & $0.00 \%$ \\
\hline 3-month JIBAR yield & $0.000 \%$ & 3-month JIBAR yield & $0.08 \%$ & Rand overnight deposit rate & $0.00 \%$ \\
\hline 6-month JIBAR yield & $0.000 \%$ & 3-month NCD rate & $0.08 \%$ & 12-month JIBAR yield & $0.00 \%$ \\
\hline 12-month JIBAR yield & $0.000 \%$ & 6-month NCD rate & $0.10 \%$ & 6-month NCD rate & $0.00 \%$ \\
\hline 3-month NCD rate & $0.000 \%$ & 12-month NCD rate & $0.11 \%$ & 3-month NCD rate & $0.00 \%$ \\
\hline 6-month NCD rate & $0.000 \%$ & 12-month JIBAR yield & $0.11 \%$ & 3-month JIBAR yield & $0.00 \%$ \\
\hline 12-month NCD rate & $0.000 \%$ & 3-month Call deposit index & $0.28 \%$ & 12 -month NCD rate & $0.00 \%$ \\
\hline 3-month T-Bill rate & $0.000 \%$ & 6-month Call deposit index & $0.66 \%$ & Overnight $\mathrm{FX}$ rate & $0.00 \%$ \\
\hline SABOR rate & $0.000 \%$ & 12-month Call deposit index & $0.68 \%$ & SABOR rate & $0.00 \%$ \\
\hline 1-to-3-year bond index & $1.116 \%$ & 1-to-3-year bond index & $1.32 \%$ & 12-month Call deposit index & $0.00 \%$ \\
\hline 3-to-7-year bond index & $2.114 \%$ & 3 -to-7-year bond index & $2.04 \%$ & 1-to-3-year bond index & $0.00 \%$ \\
\hline 6-month Call deposit index & $2.174 \%$ & 7-to-12-year bond index & $3.42 \%$ & 3 -to-7-year bond index & $0.00 \%$ \\
\hline 7-to-12-year bond index & $3.442 \%$ & 6-month JIBAR yield & $3.80 \%$ & 7-to-12-year bond index & $0.00 \%$ \\
\hline Over-12-year bond index & $4.702 \%$ & Over- 12 -year bond index & $4.76 \%$ & Over-12-year bond index & $0.00 \%$ \\
\hline
\end{tabular}

Source: Compiled by author.

Note: The JSE All Share index (J203) was used as the equity market proxy to estimate the level of covariance. 
Table C. Volatility and alternative risk and performance measures $\sim$ During financial crisis period (Ranked from best to worst)

\begin{tabular}{|c|c|c|c|c|c|}
\hline \multicolumn{2}{|c|}{ Annualised EWMA evaluation } & \multicolumn{2}{|c|}{ Annualised standard deviation } & \multicolumn{2}{|c|}{ Maximum drawdown } \\
\hline Rand overnight deposit rate & $0.98 \%$ & R157 & $0.09 \%$ & 3-month NCD rate & $0.02 \%$ \\
\hline SABOR rate & $0.99 \%$ & R203 & $0.09 \%$ & 3-month JIBAR yield & $0.02 \%$ \\
\hline 3-month T-Bill rate & $0.99 \%$ & R204 & $0.09 \%$ & SABOR rate & $0.02 \%$ \\
\hline 3-month JIBAR yield & $1.03 \%$ & 3-month T-Bill rate & $0.19 \%$ & R203 & $0.02 \%$ \\
\hline 3-month Call deposit index & $1.04 \%$ & 12-month Call deposit index & $0.20 \%$ & $\mathrm{R} 157$ & $0.03 \%$ \\
\hline Overnight FX rate & $1.05 \%$ & SABOR rate & $0.22 \%$ & R204 & $0.03 \%$ \\
\hline 6-month JIBAR yield & $1.07 \%$ & 6-month Call deposit index & $0.22 \%$ & 3-month T-Bill rate & $0.03 \%$ \\
\hline 6-month Call deposit index & $1.11 \%$ & 3-month JIBAR yield & $0.22 \%$ & 6-month JIBAR yield & $0.04 \%$ \\
\hline $\mathrm{R} 157$ & $1.11 \%$ & 6-month JIBAR yield & $0.23 \%$ & 12-month NCD rate & $0.04 \%$ \\
\hline 12-month NCD rate & $1.12 \%$ & 3-month NCD rate & $0.23 \%$ & Overnight FX rate & $0.05 \%$ \\
\hline 12-month JIBAR yield & $1.12 \%$ & 6-month NCD rate & $0.23 \%$ & 12-month JIBAR yield & $0.05 \%$ \\
\hline R203 & $1.17 \%$ & 12-month JIBAR yield & $0.23 \%$ & Rand overnight deposit rate & $0.06 \%$ \\
\hline R204 & $1.17 \%$ & 12-month NCD rate & $0.23 \%$ & 3-month Call deposit index & $0.12 \%$ \\
\hline 12-month Call deposit index & $1.25 \%$ & 3-month Call deposit index & $0.23 \%$ & 12-month Call deposit index & $0.13 \%$ \\
\hline 1-to-3-year bond index & $1.49 \%$ & 1-to-3-year bond index & $4.13 \%$ & 7-to-12-year bond index & $5.68 \%$ \\
\hline 3-to-7-year bond index & $3.47 \%$ & 7-to-12-year bond index & $6.72 \%$ & 3-to-7-year bond index & $8.35 \%$ \\
\hline 7-to-12-year bond index & $5.08 \%$ & 3-to-7-year bond index & $8.12 \%$ & 1-to-3-year bond index & $8.41 \%$ \\
\hline Over-12-year bond index & $6.96 \%$ & Over-12-year bond index & $9.74 \%$ & Over-12-year bond index & $8.55 \%$ \\
\hline \multicolumn{2}{|c|}{ Deviation in maximum drawdown } & \multicolumn{2}{|c|}{ Deviation in maximum upturn } & \multicolumn{2}{|l|}{ Geometric return } \\
\hline 3-month JIBAR yield & $0.00 \%$ & SABOR rate & $0.00 \%$ & 12-month JIBAR yield & $10.43 \%$ \\
\hline $\mathrm{R} 186$ & $0.01 \%$ & 6-month NCD rate & $0.00 \%$ & 12-month NCD rate & $10.42 \%$ \\
\hline 3-month NCD rate & $0.01 \%$ & 3-month NCD rate & $0.00 \%$ & 12-month Call deposit index & $10.24 \%$ \\
\hline SABOR rate & $0.01 \%$ & 3-month T-Bill rate & $0.00 \%$ & 6-month JIBAR yield & $10.14 \%$ \\
\hline R157 & $0.01 \%$ & $\mathrm{R} 186$ & $0.01 \%$ & 6-month NCD rate & $10.14 \%$ \\
\hline R203 & $0.01 \%$ & R157 & $0.01 \%$ & Overnight FX rate & $9.99 \%$ \\
\hline R204 & $0.01 \%$ & R203 & $0.01 \%$ & 3-month JIBAR yield & $9.97 \%$ \\
\hline 12-month NCD rate & $0.01 \%$ & R204 & $0.01 \%$ & 3-month NCD rate & $9.96 \%$ \\
\hline 6-month NCD rate & $0.01 \%$ & 12-month NCD rate & $0.01 \%$ & 6-month Call deposit index & $9.93 \%$ \\
\hline 12-month JIBAR yield & $0.01 \%$ & Overnight FX rate & $0.01 \%$ & Rand overnight deposit rate & $9.48 \%$ \\
\hline Overnight FX rate & $0.01 \%$ & 3-month JIBAR yield & $0.01 \%$ & 3-month T-Bill rate & $9.25 \%$ \\
\hline Rand overnight deposit rate & $0.02 \%$ & Rand overnight deposit rate & $0.01 \%$ & R203 & $8.57 \%$ \\
\hline 3-month Call deposit index & $0.03 \%$ & 3-month Call deposit index & $0.03 \%$ & R204 & $8.56 \%$ \\
\hline 6-month Call deposit index & $0.03 \%$ & 6-month Call deposit index & $0.04 \%$ & $\mathrm{R} 157$ & $8.46 \%$ \\
\hline 12-month Call deposit index & $0.03 \%$ & 12-month Call deposit index & $0.04 \%$ & $\mathrm{R} 186$ & $8.46 \%$ \\
\hline 7-to-12-year bond index & $1.09 \%$ & 1-to-3-year bond index & $0.96 \%$ & 3-to-7-year bond index & $-2.26 \%$ \\
\hline 1-to-3-year bond index & $1.24 \%$ & 7-to-12-year bond index & $1.20 \%$ & 1-to-3-year bond index & $-2.68 \%$ \\
\hline Over-12-year bond index & $1.50 \%$ & Over-12-year bond index & $1.65 \%$ & 7-to-12-year bond index & $-3.20 \%$ \\
\hline 3-to-7-year bond index & $1.89 \%$ & 3-to-7-year bond index & $2.31 \%$ & Over-12-year bond index & $-5.20 \%$ \\
\hline
\end{tabular}


(Table C continued)

\begin{tabular}{|c|c|c|c|c|c|}
\hline \multicolumn{2}{|l|}{ Downside risk } & \multicolumn{2}{|l|}{ Upside risk } & \multicolumn{2}{|c|}{$\begin{array}{l}\text { Annualised covariance with } \\
\text { equity market proxy }\end{array}$} \\
\hline 3-month Call deposit index & $0.000 \%$ & R157 & $0.09 \%$ & 12-month JIBAR yield & $0.00 \%$ \\
\hline 6-month Call deposit index & $0.000 \%$ & R203 & $0.09 \%$ & 3-month NCD rate & $0.00 \%$ \\
\hline 12-month Call deposit index & $0.000 \%$ & R204 & $0.09 \%$ & 6-month JIBAR yield & $0.00 \%$ \\
\hline Overnight FX rate & $0.000 \%$ & $\mathrm{R} 186$ & $0.09 \%$ & 12-month NCD rate & $0.00 \%$ \\
\hline R157 & $0.000 \%$ & 3-month T-Bill rate & $0.19 \%$ & 3-month JIBAR yield & $0.00 \%$ \\
\hline R186 & $0.000 \%$ & 12-month Call deposit index & $0.20 \%$ & 6-month NCD rate & $0.00 \%$ \\
\hline R203 & $0.000 \%$ & SABOR rate & $0.22 \%$ & Overnight FX rate & $0.00 \%$ \\
\hline R204 & $0.000 \%$ & Rand overnight deposit rate & $0.22 \%$ & SABOR rate & $0.00 \%$ \\
\hline Rand overnight deposit rate & $0.000 \%$ & 6-month Call deposit index & $0.22 \%$ & 3-month T-Bill rate & $0.00 \%$ \\
\hline 3-month JIBAR yield & $0.000 \%$ & 3-month JIBAR yield & $0.22 \%$ & 3-month Call deposit index & $0.00 \%$ \\
\hline 6-month JIBAR yield & $0.000 \%$ & 6-month JIBAR yield & $0.23 \%$ & Rand overnight deposit rate & $0.00 \%$ \\
\hline 12-month JIBAR yield & $0.000 \%$ & 3-month NCD rate & $0.23 \%$ & 6-month Call deposit index & $0.00 \%$ \\
\hline 3-month NCD rate & $0.000 \%$ & 6-month NCD rate & $0.23 \%$ & 12-month Call deposit index & $0.00 \%$ \\
\hline 6-month NCD rate & $0.000 \%$ & 12-month JIBAR yield & $0.23 \%$ & R157 & $0.00 \%$ \\
\hline 12-month NCD rate & $0.000 \%$ & 12-month NCD rate & $0.23 \%$ & R186 & $0.00 \%$ \\
\hline 3-month T-Bill rate & $0.000 \%$ & Overnight FX rate & $0.23 \%$ & R203 & $0.00 \%$ \\
\hline SABOR rate & $0.000 \%$ & 3-month Call deposit index & $0.23 \%$ & R204 & $0.00 \%$ \\
\hline 1-to-3-year bond index & $3.767 \%$ & 1-to-3-year bond index & $3.51 \%$ & 3-to-7-year bond index & $0.00 \%$ \\
\hline 7-to-12-year bond index & $3.994 \%$ & 7-to-12-year bond index & $5.42 \%$ & 1-to-3-year bond index & $0.00 \%$ \\
\hline 3-to-7-year bond index & $5.597 \%$ & Over- 12 -year bond index & $7.58 \%$ & 7-to-12-year bond index & $0.00 \%$ \\
\hline Over-12-year bond index & $5.743 \%$ & 3-to-7-year bond index & $8.27 \%$ & Over-12-year bond index & $0.00 \%$ \\
\hline
\end{tabular}

Source: Compiled by author.

Note: The JSE All Share index (J203) was used as the equity market proxy to estimate the level of covariance. 
Table D: Volatility and alternative risk and performance measures $\sim$ Post-financial crisis period (Ranked from best to worst)

\begin{tabular}{|c|c|c|c|c|c|}
\hline \multicolumn{2}{|c|}{ Annualised EWMA evaluation } & \multicolumn{2}{|c|}{ Annualised standard deviation } & \multicolumn{2}{|c|}{ Maximum drawdown } \\
\hline Rand overnight deposit rate & $0.71 \%$ & R186 & $0.07 \%$ & 3-month NCD rate & $0.00 \%$ \\
\hline SABOR rate & $0.73 \%$ & Rand overnight deposit rate & $0.07 \%$ & 3-month T-Bill rate & $0.01 \%$ \\
\hline 3-month Call deposit index & $0.74 \%$ & SABOR rate & $0.07 \%$ & 6-month NCD rate & $0.01 \%$ \\
\hline 3-month JIBAR yield & $0.78 \%$ & 3-month NCD rate & $0.07 \%$ & 3-month JIBAR yield & $0.01 \%$ \\
\hline 3-month T-Bill rate & $0.78 \%$ & 3-month JIBAR yield & $0.07 \%$ & Rand overnight deposit rate & $0.01 \%$ \\
\hline 3-month NCD rate & $0.78 \%$ & 6-month NCD rate & $0.08 \%$ & 12-month NCD rate & $0.01 \%$ \\
\hline 12-month Call deposit index & $0.82 \%$ & Overnight FX rate & $0.08 \%$ & 6-month JIBAR yield & $0.01 \%$ \\
\hline 6-month JIBAR yield & $0.85 \%$ & 12-month NCD rate & $0.09 \%$ & R204 & $0.02 \%$ \\
\hline 6-month NCD rate & $0.85 \%$ & 12-month JIBAR yield & $0.09 \%$ & R186 & $0.02 \%$ \\
\hline $\mathrm{R} 157$ & $0.89 \%$ & 3-month Call deposit index & $0.10 \%$ & R203 & $0.02 \%$ \\
\hline 12-month NCD rate & $0.92 \%$ & 6-month Call deposit index & $0.11 \%$ & R157 & $0.02 \%$ \\
\hline 12-month JIBAR yield & $0.93 \%$ & $\mathrm{R} 157$ & $0.12 \%$ & Overnight $\mathrm{FX}$ rate & $0.03 \%$ \\
\hline R203 & $0.98 \%$ & R204 & $0.12 \%$ & 3-month Call deposit index & $0.06 \%$ \\
\hline R186 & $1.10 \%$ & R203 & $0.13 \%$ & 12-month Call deposit index & $0.07 \%$ \\
\hline 1-to-3-year bond index & $1.35 \%$ & 1-to-3-year bond index & $1.50 \%$ & 1-to-3-year bond index & $1.22 \%$ \\
\hline 3-to-7-year bond index & $3.36 \%$ & 3-to-7-year bond index & $3.51 \%$ & 3-to-7-year bond index & $2.67 \%$ \\
\hline 7-to-12-year bond index & $5.06 \%$ & 7-to-12-year bond index & $5.42 \%$ & 7-to-12-year bond index & $3.61 \%$ \\
\hline Over-12-year bond index & $6.27 \%$ & Over-12-year bond index & $7.38 \%$ & Over-12-year bond index & $5.09 \%$ \\
\hline \multicolumn{2}{|c|}{ Deviation in maximum drawdown } & \multicolumn{2}{|c|}{ Deviation in maximum upturn } & \multicolumn{2}{|c|}{ Geometric return } \\
\hline 3-month NCD rate & $0.00 \%$ & SABOR rate & $0.00 \%$ & R186 & $8.21 \%$ \\
\hline 6-month NCD rate & $0.00 \%$ & 3-month NCD rate & $0.00 \%$ & R204 & $7.53 \%$ \\
\hline 3-month T-Bill rate & $0.00 \%$ & Rand overnight deposit rate & $0.00 \%$ & R203 & $7.33 \%$ \\
\hline Rand overnight deposit rate & $0.00 \%$ & 3-month JIBAR yield & $0.00 \%$ & $\mathrm{R} 157$ & $6.69 \%$ \\
\hline SABOR rate & $0.00 \%$ & 3-month T-Bill rate & $0.00 \%$ & 12-month JIBAR yield & $6.32 \%$ \\
\hline 12-month NCD rate & $0.00 \%$ & 6-month JIBAR yield & $0.00 \%$ & 12-month Call deposit index & $6.31 \%$ \\
\hline 6-month JIBAR yield & $0.00 \%$ & 6-month NCD rate & $0.00 \%$ & 12-month NCD rate & $6.30 \%$ \\
\hline R157 & $0.00 \%$ & 12-month JIBAR yield & $0.00 \%$ & 6-month JIBAR yield & $5.96 \%$ \\
\hline 12-month JIBAR yield & $0.00 \%$ & Overnight FX rate & $0.00 \%$ & 6-month NCD rate & $5.95 \%$ \\
\hline 3-month JIBAR yield & $0.00 \%$ & R203 & $0.00 \%$ & 3-month NCD rate & $5.65 \%$ \\
\hline $\mathrm{R} 186$ & $0.00 \%$ & R204 & $0.00 \%$ & Overnight FX rate & $5.59 \%$ \\
\hline Overnight FX rate & $0.01 \%$ & $\mathrm{R} 157$ & $0.01 \%$ & 3-month T-Bill rate & $5.59 \%$ \\
\hline 3-month Call deposit index & $0.01 \%$ & 3-month Call deposit index & $0.01 \%$ & 3-month Call deposit index & $5.54 \%$ \\
\hline 6-month Call deposit index & $0.01 \%$ & 6-month Call deposit index & $0.01 \%$ & SABOR rate & $5.33 \%$ \\
\hline 12-month Call deposit index & $0.01 \%$ & 12-month Call deposit index & $0.01 \%$ & Rand overnight deposit rate & $5.29 \%$ \\
\hline 1-to-3-year bond index & $0.25 \%$ & 1-to-3-year bond index & $0.27 \%$ & 7-to-12-year bond index & $1.34 \%$ \\
\hline 3-to-7-year bond index & $0.54 \%$ & 3-to-7-year bond index & $0.55 \%$ & Over-12-year bond index & $0.39 \%$ \\
\hline 7-to-12-year bond index & $0.80 \%$ & 7-to-12-year bond index & $0.75 \%$ & 3-to-7-year bond index & $-0.22 \%$ \\
\hline Over-12-year bond index & $1.10 \%$ & Over-12-year bond index & $0.86 \%$ & 1-to-3-year bond index & $-3.09 \%$ \\
\hline
\end{tabular}


(Table D continued)

\begin{tabular}{|c|c|c|c|c|c|}
\hline \multicolumn{2}{|l|}{ Downside risk } & \multicolumn{2}{|l|}{ Upside risk } & \multicolumn{2}{|c|}{$\begin{array}{c}\text { Annualised covariance with } \\
\text { equity market proxy }\end{array}$} \\
\hline 3-month Call deposit index & $0.000 \%$ & R186 & $0.07 \%$ & R157 & $0.00 \%$ \\
\hline 6-month Call deposit index & $0.000 \%$ & Rand overnight deposit rate & $0.07 \%$ & $\mathrm{R} 186$ & $0.00 \%$ \\
\hline 12-month Call deposit index & $0.000 \%$ & SABOR rate & $0.07 \%$ & 12-month NCD rate & $0.00 \%$ \\
\hline Overnight FX rate & $0.000 \%$ & 3-month T-Bill rate & $0.07 \%$ & 12-month JIBAR yield & $0.00 \%$ \\
\hline R157 & $0.000 \%$ & 3-month NCD rate & $0.07 \%$ & 6-month NCD rate & $0.00 \%$ \\
\hline R186 & $0.000 \%$ & 3-month JIBAR yield & $0.07 \%$ & 12-month Call deposit index & $0.00 \%$ \\
\hline R203 & $0.000 \%$ & 6-month NCD rate & $0.08 \%$ & Overnight FX rate & $0.00 \%$ \\
\hline R204 & $0.000 \%$ & 6-month JIBAR yield & $0.08 \%$ & 6-month JIBAR yield & $0.00 \%$ \\
\hline Rand overnight deposit rate & $0.000 \%$ & Overnight FX rate & $0.08 \%$ & 3-month NCD rate & $0.00 \%$ \\
\hline 3-month JIBAR yield & $0.000 \%$ & 12-month NCD rate & $0.09 \%$ & 3-month T-Bill rate & $0.00 \%$ \\
\hline 6-month JIBAR yield & $0.000 \%$ & 12-month JIBAR yield & $0.09 \%$ & 6-month Call deposit index & $0.00 \%$ \\
\hline 12-month JIBAR yield & $0.000 \%$ & 3-month Call deposit index & $0.10 \%$ & 3-month JIBAR yield & $0.00 \%$ \\
\hline 3-month NCD rate & $0.000 \%$ & 6-month Call deposit index & $0.11 \%$ & 3-month Call deposit index & $0.00 \%$ \\
\hline 6-month NCD rate & $0.000 \%$ & R157 & $0.12 \%$ & SABOR rate & $0.00 \%$ \\
\hline 12-month NCD rate & $0.000 \%$ & R204 & $0.12 \%$ & Rand overnight deposit rate & $0.00 \%$ \\
\hline 3-month T-Bill rate & $0.000 \%$ & 12-month Call deposit index & $0.12 \%$ & $\mathrm{R} 203$ & $0.00 \%$ \\
\hline SABOR rate & $0.000 \%$ & R203 & $0.13 \%$ & R204 & $0.00 \%$ \\
\hline 1-to-3-year bond index & $1.208 \%$ & 1-to-3-year bond index & $0.84 \%$ & 1-to-3-year bond index & $0.00 \%$ \\
\hline 3-to-7-year bond index & $3.014 \%$ & 3-to-7-year bond index & $1.73 \%$ & 3-to-7-year bond index & $0.00 \%$ \\
\hline 7-to-12-year bond index & $4.314 \%$ & 7-to-12-year bond index & $2.93 \%$ & 7-to-12-year bond index & $0.00 \%$ \\
\hline Over-12-year bond index & $5.170 \%$ & Over-12-year bond index & $4.52 \%$ & Over-12-year bond index & $0.00 \%$ \\
\hline
\end{tabular}

Source: Compiled by author.

Note: The JSE All Share index (J203) was used as the equity market proxy to estimate the level of covariance. 